\title{
Gender and Mortuary Ritual at Ancient Teotihuacan, Mexico: a Study of Intrasocietal Diversity
}

\author{
Sarah C. Clayton
}

\begin{abstract}
Archaeologists increasingly recognize a need to revise the scales at which we investigate identities such as gender, class and faction in ancient complex societies. In this article I present research on the expression of gender roles and ideologies in the performance of mortuary ritual in four distinctive residential areas of Classic Teotihuacan, including the urban compounds of La Ventilla 3, Tlajinga 33 and Tlailotlacan 6 and the hinterland settlement of Axotlan. Results indicate that gender was constructed and experienced differently across Teotihuacan society. This research demonstrates that multiscalar, comparative approaches to social identity make possible a fuller understanding of the significance of social heterogeneity in structuring early states.
\end{abstract}

In a distinguished lecture criticizing the ecosystem approach, Brumfiel $(1992,551)$ argued that approaching whole societies as units of analysis 'obscures the visibility of gender, class, and faction' in the past. This point is particularly salient when it comes to early states, many of which were multiethnic amalgamations of individuals whose cultural backgrounds, socioeconomic positions and life experiences varied widely. Recent research focused on identity and intrasocietal heterogeneity within Mesoamerican complex societies has considerably advanced our knowledge of their diverse social composition (e.g. Hendon 2007; Manzanilla 2009a; McCafferty 2007; Robertson 2001; Robin 2004; Spence et al. 2005; Stark 2008; White et al. 2004, among others). Research that explores gender as an important dimension of this diversity is promising, not just because it reveals differences in the social roles and activities of men and women. Variation in gender organization among diverse sectors of societies (such as elites and commoners, rural and urban residents, immigrants and mainstream society) speaks to the relationships and potential sources of tension among such groups. At stake is a fuller comprehension of the social topography of early states as well as their modes of sociopolitical integration.

In this article I examine gender roles and ideologies in the ancient complex society of Teotihuacan, located in the central Mexican highlands (Fig. 1). This research is aimed at improving our understanding of social organization and diversity within Teotihuacan's large population of urban and rural commoners. I follow Brumfiel $(2001,57)$ in defining gender roles as the economic, political, and cultural activities of men and women and gender ideologies as the expectations, associations, and sentiments attached to gender categories.

Social identities such as gender are constituted through human interaction and are, therefore, most effectively approached at the scales at which social interaction frequently occurs. Research concerning gender and other facets of identity most productively centres on households and communities, which are fundamental loci of social conditioning and reproduction (Cohen 1985, 15; Robertson 2001, 1-3; Watanabe 1992, 11-13; Yaeger 2000). In this study I consider the gender constructs evident in mortuary ritual at four distinctive residential groups representing both urban and rural sectors of Teotihuacan society. These include the urban compounds of La Ventilla 3 (Gómez Chávez 2000), Tlajinga 33 (Storey \& Widmer 1989), and Tlailotlacan 6 (Spence \& Gamboa Cabezas 1999) (Fig. 2) and a rural settlement called Axotlan. Axotlan, located about $35 \mathrm{~km}$ west of Teotihuacan in the Cuautitlan region, was recently excavated by Raúl García, Luis Gamboa, and Nadia Vélez (García Chávez et al. 2004). I include Axotlan in this study because Teotihuacan was 


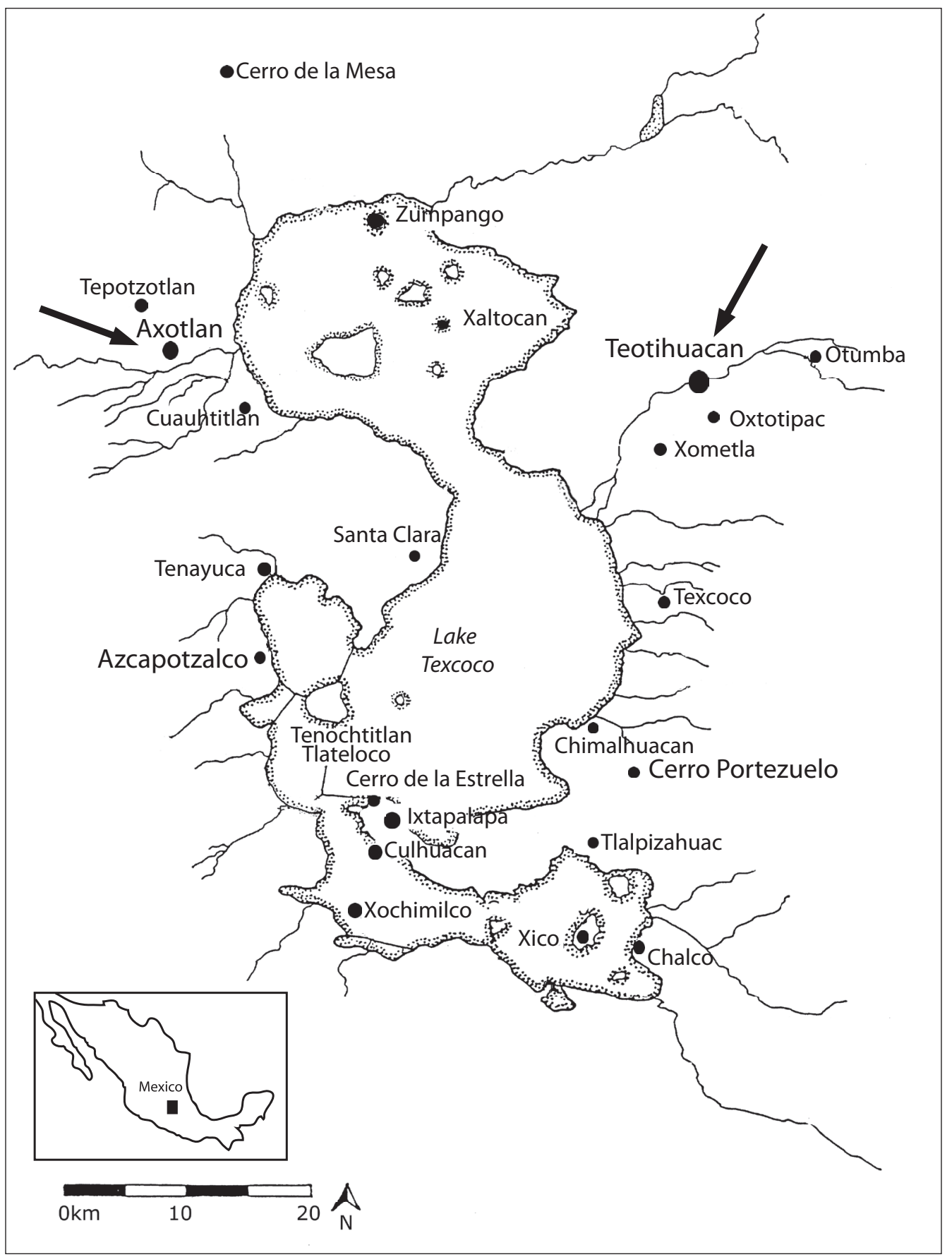

Figure 1. The Prehispanic Basin of Mexico; arrows highlight the sites discussed, Axotlan and Teotihuacan.

a regional phenomenon that comprised a rural as well as an urban population. These components must be considered together in order to develop a more holistic understanding of the social structure of the state.

Results of this study indicate that gender was shaped primarily through social interactions that occurred in the context of domestic groups. Further- more, gender arrangements and ideologies constituted a significant dimension of intrasocietal variation within the general population of Teotihuacan. Marked variation in mortuary practices associated with males and females among residential groups indicates that gender identities were constructed and experienced differently across Teotihuacan society. 


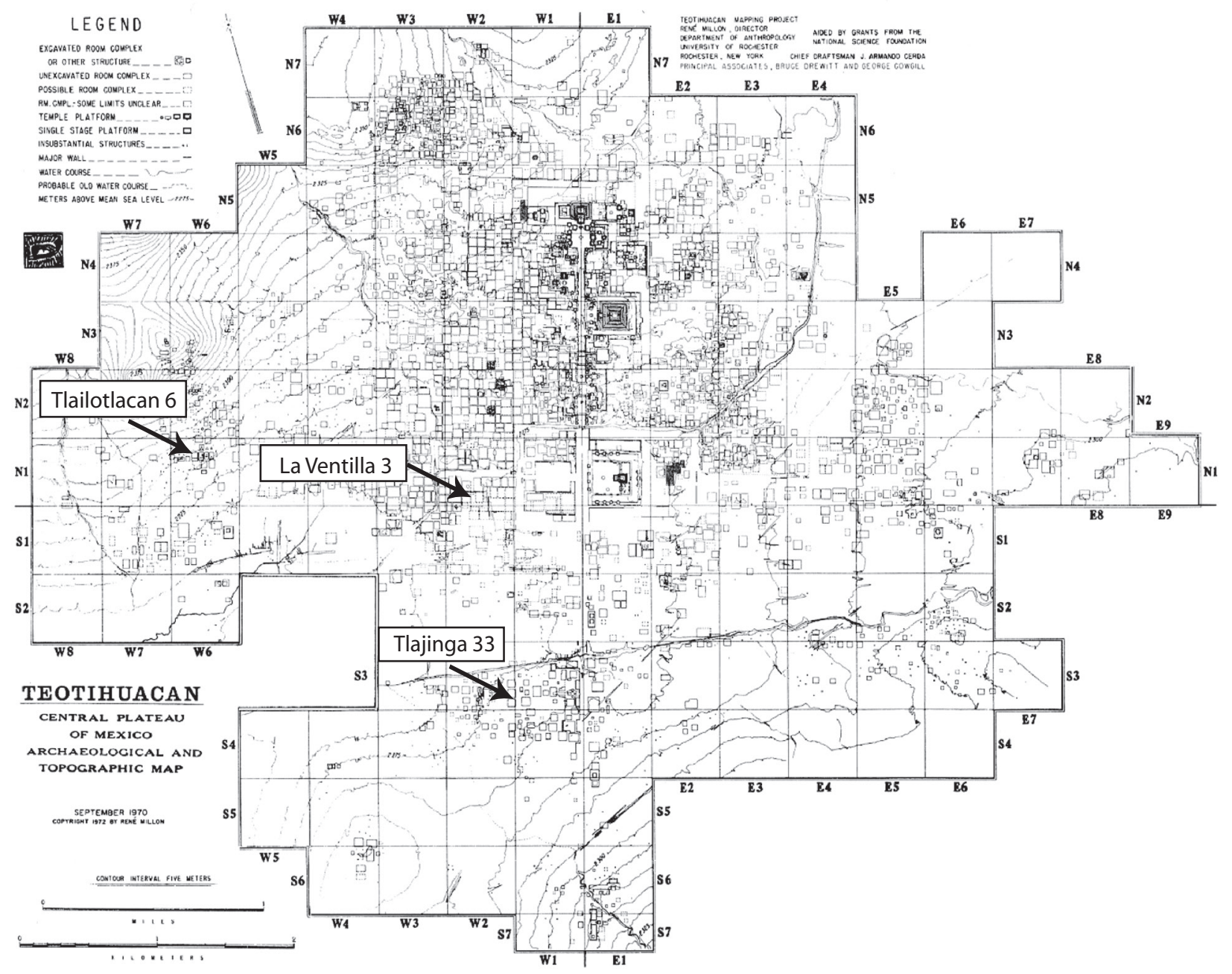

Figure 2. Teotihuacan Mapping Project map showing the urban compounds included in this study. Based on the 1:40,000 scale map published in Millon 1973 (Map 1).

\section{Biological bodies and cultural categories}

Gender is not the same as biological sex, although there is no consensus among anthropologists on the precise relationship between these concepts. Arnold $(2001,239)$ suggests that sex and gender are interconnected continua, wherein a complex set of biological configurations intersects with a complex set of gender configurations. Joyce (2000) and Hays-Gilpin (2004, 36) depict gender as inscribed on sexual difference through cultural practices (e.g. activities, ways of speaking and posture) and visual cues (e.g. clothing and hair styles). Most anthropologists agree that gender is not binary but comprises multiple, dynamic categories. Some go further, stressing the entanglements between biological sex and cultural categories. They question the separation of gender as cultural and sex as biological, fixed and binary (e.g. Blackless et al. 2000; Geller 2005; Fausto-Sterling 2000).

If the articulation of gender with sex and emic perceptions of these categories are complicated issues in socio-cultural research concerning living societies, archaeologists interested in gender in ancient societies face an even greater challenge. We must approach these cultural constructs through the material traces of human activities and, if possible, through material associations with bodies categorized as male or female. An individual's biological sex intersects with several constructs of identity (Arnold 2006, 150; Brumfiel 2006, 32; Conkey \& Gero 1991; Geller 2009, 70; Joyce 2008; Strathern 1988), including age, ethnicity, occupation, status and house membership. It is not sex, but the articulation of sex with other facets of life that constitutes gender. 
My investigation of gender begins with a binary categorization of male and female biological bodies. However, this approach is (and must be) coupled with attention to other aspects of social life, since male and female bodies do not map unproblematically onto the full range of gender categories in any society. Specifically, I consider the intersection of sex with membership in particular domestic groups. This is, therefore, a study of gender variation across Teotihuacan society, although it does not claim to address the entire realm of gendered experience. Despite the constraints of binary sexual categories, the identification of mortuary practices associated with females and males is a step toward understanding gender roles and ideologies at Teotihuacan.

\section{Gender and mortuary ritual}

Archaeologists have long utilized mortuary data to investigate gender relations in ancient societies. Burials lend themselves to the study of social identity for many reasons. First, the ritual practices associated with burials are important means of constituting social relations (Bell 1997; Kertzer 1991; Rappaport 1979; 1984). Ritual actions are central not only to beliefs or ideological constructs, but also to human relationships (Rappaport 1984, 410). These actions delineate social groups as distinctive or connected (Kertzer 1988; 1991). Beyond the fact that mortuary ritual is important in structuring relations among individuals, the presence of human skeletons, whose sex and approximate age can often be determined, is a clear benefit for investigations of identity. Patterned associations of particular materials with one or the other sex, for example, provide evidence for the behaviours that males and females engaged in during their lives. The degree of difference or congruence in the burials of males and females provides a measure of the salience of sex in structuring social dynamics. Even so, there are certain precautions that archaeologists must take in drawing connections between how individuals were buried and how they actually lived their lives.

Burials are conscious creations through which social relations are actively constituted (Brumfiel 2006, 38; Joyce 2001; Parker Pearson 1982). Although archaeologists have often viewed burials as reflections of the social personae of the dead (e.g. Binford 1971), many now recognize that such reflections are not straightforward. Parker Pearson $(1999,32)$, for example, cautions archaeologists to consider the possible disjunctures between ordinary social circumstances and funerary ritual. The latter, he notes, is often concerned with idealized roles and relations that "may refer more to the imagined past than the experienced present'. Brumfiel $(2006,38)$ also emphasizes burials as expressions of ideology that may or may not coincide with actual daily practice - in other words, the experiences, social roles and obligations of the deceased individual. The distinction between social realities and ideological constructs is significant and must be born in mind by archaeologists investigating social organization using mortuary data. This does not negate the importance of mortuary analysis for understanding the social and ideological structures of past societies. On the contrary, the activities and roles that an individual engaged in during his or her life and the beliefs espoused by participants in funerary ritual are often concurrently expressed in the actions that culminate in burial. As Parker Pearson $(1999,33)$ notes, funerary rituals are not ideological masks of reality; rather, they are one arena of social representation among many. Therefore, it is entirely possible to access actual social relations as well as ideological dispositions archaeologically, acknowledging that distinct areas of the human experience may be emphasized or muted in funerary contexts.

For example, patterned associations of particular artefacts with either males or females may imply a gendered division of labour (Brumfiel 2006, 39). Such material patterning may reflect, in a quite tangible way, the social roles and lived experiences of gendered individuals. In contrast, the practice of arranging male and female bodies into particular positions or directions may express beliefs concerning the afterlife or adherence to religious or ethnic canons. Such traditions may connect only loosely to quotidian activities and differences in the daily lives of men and women.

Multiple aspects of the process of mortuary ritual are considered here in order to better understand the social roles of men and women at Teotihuacan as well as the gender ideologies that characterized distinctive residential groups. Two main lines of evidence are investigated. First, I consider the materials associated with females and males as burial accoutrements, focusing on whether there was disparity or relative equality between the sexes in the presence of grave goods as well as in the kinds of objects used. Striking differences in quantity and kind of burial accoutrements associated with males and females would suggest that sex was salient in determining the social roles and perhaps relative valuation of individuals. Similarities in the materials associated with males and females and relative equality in the quantity of grave goods would support an alternative hypothesis that sex was not a significant factor in structuring social dynamics. 
Second, I discuss practices pertaining to the arrangement of the bodies of females and males for burial - specifically, their position and cardinal orientation. The precise meaning of body position and orientation for ritual participants cannot be gleaned from an etic, archaeological perspective; however, associations between bodily arrangement and other variables, such as biological sex, provide clues as to the ideological significance of practices pertaining to the body. Moreover, socio-spatial patterns - that is, differences and similarities among residential groups - with respect to body arrangement provide valuable information regarding affiliations and distinctions among such groups. Specifically, groups that shared in the perpetuation of these practices espoused mutually recognized beliefs concerning the appropriate manipulation of the body at death, given certain conditions. These conditions may have included the gender identity of the individual, his or her particular social roles, the cause or circumstances of death, and the anticipated destination of the soul (see Carr 1995).

\section{State, society, and gender at Teotihuacan}

Teotihuacan was a densely populated metropolis that thrived from the first century вС to AD 550/650 (Fig. 3). From about AD 200 to 600 an estimated 125,000 people inhabited the city (Millon 1973; 1981, 208), which was the administrative and economic capital of a powerful, expansionist state. As one of the earliest urban and ethnically plural societies in the Americas (Clayton 2005; Spence et al. 2005; White et al. 2004), Teotihuacan has long captivated archaeologists and the general public. Its urban population comprised a mosaic of farmers, craft specialists and immigrants, most of whom lived in some 2300 apartment compounds located across the city. Teotihuacan's population was not limited, however, to the capital. The state also exercised power over several rural settlements, from which it derived many resources necessary for sustaining the urban population (Charlton 1991; 2000; Clayton 2008; Sanders et al. 1979). Abundant research on settlement, economy, palaeodemography and public and domestic ritual has generated a clearer picture of Teotihuacan society. Nevertheless, there is much to be learned about what life was like for ordinary members of the urban and rural population.

Archaeological research on the role of gender in structuring social dynamics at Teotihuacan has been particularly sparse, although some have made significant contributions to this issue. For example,

\begin{tabular}{|c|c|c|c|}
\hline General chronology & \multicolumn{3}{|c|}{ Teotihuacan Valley phases } \\
\hline \multirow{2}{*}{$\begin{array}{l}\text { Early Postclassic Period } \\
\text { (AD 850-1150) }\end{array}$} & \multicolumn{2}{|l|}{ Atlatongo } & AD $950-1150$ \\
\hline & \multicolumn{2}{|l|}{ Mazapan } & AD 850-950 \\
\hline $\begin{array}{l}\text { Epiclassic Period } \\
\text { (AD 650-850) }\end{array}$ & \multicolumn{2}{|l|}{ Coyotlatelco } & AD $650-850$ \\
\hline \multirow{5}{*}{$\begin{array}{l}\text { Early Classic Period } \\
\text { (AD 250-650) }\end{array}$} & \multicolumn{2}{|l|}{ Metepec } & AD 550-650 \\
\hline & \multirow{2}{*}{ Xolalpan } & Late & AD 450-550 \\
\hline & & Early & AD 350-450 \\
\hline & \multirow{2}{*}{ Tlamimilolpa } & Late & AD 275-350 \\
\hline & & Early & AD 200-275 \\
\hline \multirow{3}{*}{$\begin{array}{l}\text { Late and Terminal } \\
\text { Formative Period } \\
(300 \text { BC-AD 200) }\end{array}$} & \multicolumn{2}{|l|}{ Miccaotli } & AD 125-200 \\
\hline & \multicolumn{2}{|l|}{ Tzacualli } & AD $1-125$ \\
\hline & \multicolumn{2}{|l|}{ Patlachique } & $100-1$ вс \\
\hline
\end{tabular}

Figure 3. Mesoamerican general chronology and Teotihuacan phases.

Sempowski (1994, 260-61) conducted an impressive investigation of social status at Teotihuacan based on mortuary data. As part of this effort, she compared the burials of males and females across Teotihuacan society, concluding that males generally had higher status than females. More recent research on the relative mortuary treatments of males and females within specific domestic areas suggests that the picture was far more complex. Spence \& Gamboa Cabezas (1999), for example, have indicated that males and females living in Tlailotlacan, a Zapotec enclave at Teotihuacan, probably enjoyed relatively equal social status. They suggest that this situation differed from mainstream Teotihuacan society $(1999,195)$. De Lucia (2008) cogently argues that gender constructs at Teotihuacan may have been overshadowed by other forms of group identity. She suggests that gender was largely insignificant in determining an individual's general social status vis-à-vis greater Teotihuacan society.

These recent perspectives highlight the importance of scale in archaeological research on gender and other modes of social identification. I focus here on the social groups that resided together in compounds, and pursue this study under the reasonable assumption that individuals living together in these structures interacted regularly. Contextualizing gender within domestic groups makes it possible to identify social and ideological commonalities and distinctions among these groups, thereby facilitating a more comprehensive view of the social structure of ancient Teotihuacan. 


\section{Residential organization and social identity at Teotihuacan}

Most members of Teotihuacan's population lived in multi-roomed structures called apartment compounds (Millon 1973; 1981; 1988). Compounds housed from 60 to 100 individuals (Millon 1981, 206), comprising several nuclear families (Manzanilla 2002; 2009a, 3). These family groups occupied separate suites of rooms but likely congregated in shared courtyards for ritual and social activities; Manzanilla $(2002,46)$ cites the 'Red Courtyard' at Oztoyahualco as an example of such a gathering space. Many Teotihuacanos were ultimately buried under the floors of domestic and ceremonial spaces within the compounds where they had presumably lived during at least part of their lives (Sempowski 1994; Uruñuela \& Plunket 2002, 30; White et al. 2004).

Many of Teotihuacan's urban compounds shared certain architectural features, such as thick exterior walls and an orientation of close to $15.5^{\circ}$ east of north, which aligned with Teotihuacan's major civic monuments and thoroughfares (Cowgill 2007, 268). Compounds were part of the rural landscape as well; at least two large compounds housed individuals living at the rural settlement of Axotlan. Here they varied in construction quality, suggesting that status and wealth differentiation was a fact of life at this settlement (García Chávez et al. 2005). They too were oriented to $15.5^{\circ}$ east of north but lacked the thick exterior walls typical of Teotihuacan's urban compounds.

The mode of residential organization at Teotihuacan raises many questions. For example, how did co-residents of apartment compounds relate to each other socially? What kinds of social units did they represent, in what contexts did they interact with other such co-residing groups, and did these groups differ from each other in significant ways?

Several authors (e.g. Cowgill 2007; De Lucia 2008; Headrick 2007; Manzanilla 2007; 2009b; Uruñuela \& Plunket 2007, 39) have suggested that the core residents of Teotihuacan's compounds may have belonged to social houses. The house (Chance 2000; Joyce \& Gillespie 2000) is difficult to verify archaeologically, but provides a useful framework for considering compound co-residence as a socially-identifying condition. Moreover, this model is consistent with current data pertaining to the social and economic organization of Teotihuacan's compound groups, a point that I discuss in further detail below.

The house was originally defined by Claude Lévi-Strauss (1982, 174; 1987, 152) as a corporate body organized by shared residence and means of production. House ties involve a commitment to the preservation of a corpus of property, which centres on land and architecture (Lévi-Strauss 1982), which, in turn, serve to materialize the group. The estate of the house supersedes kinship, which is, nonetheless, often central to structuring and defining house relations (Chance 2000, 485). Lévi-Strauss stressed the use of a 'language of kinship and affinity' to bind house members together and to perpetuate the estate from which their identity is derived (see Gillespie 2000b, 23).

Beyond architecture and land, house membership also entails rights to less tangible resources, including particular rituals, stories, songs, symbols and titles. As outlined by Gillespie (2000a, 9),

Houses are concerned with locale, subsistence, production, religion, gender, rank, wealth, and power which, in certain societies, are expressed in principles and strategies of consanguinity and affinity. Furthermore, the continued existence of a house is dependent on the successful execution of strategies for maintaining its estate and reproducing its members over multiple generations ...

Compound residential groups at Teotihuacan are generally understood to have been corporate bodies (Millon 1973, 40; 1981, 208) organized not only by shared residence but by economic production (Cowgill et al. 1984; Millon 1973; 1981, 208). Many of Teotihuacan's compounds were continuously occupied for several centuries, from their construction in the Early Tlamimilolpa phase until the dissolution of the state around AD 650. Some compounds were evidently occupied by a core group of biologicallyrelated individuals with a bias toward males (Spence 1974), suggestive of patrilocal residential organization. However, many compounds incorporated immigrants who were probably not blood relatives (Spence et al. 2005; White et al. 2004). Consistent with the house model, compounds were evidently occupied by kin-like, although not always biologically-related, groups. These groups often participated in economic activities together and maintained long-term ties to the compound through ritual practices such as burying their dead under the floors of domestic areas or communal courtyards.

The house concept has heuristic utility for understanding how processes of social reproduction through economic and ritual activities may have been linked to particular residential locales. This model gives meaning to ritual practices and objects as the materialization of group identity (as house memory), rather than simply as reflections of relative wealth or status. Houses at Teotihuacan would likely have interacted with each other and formed alliances for the 
exchange of marriage partners and material resources, as well as to pursue shared political and religious objectives. Grounding this research in the concept of houses makes it possible to consider in fuller measure the internal social structures of Teotihuacan's residential groups, including their gender arrangements, and a comparative investigation of social organization among Teotihuacan's hypothesized houses facilitates consideration of social heterogeneity on a larger (societal) scale.

\section{Data and analysis}

Data for this study derive from mortuary contexts at the four residential areas discussed above. These data were generated as part of a larger study of ritual and social diversity at Teotihuacan, which included gender roles and ideologies as a major component, alongside other axes of intrasocietal variation (Clayton 2009). Individuals ranging in age from perinatal to more than 40 years are represented in burials from each of the areas investigated. I focus this discussion on adults, whose biological sex could often be determined through osteological analysis. ${ }^{1}$ In total, 237 adult individuals, comprising 60 females, 73 males and 95 individuals of indeterminate sex are included in the analyses presented (Table 1). Table 2 provides the probable age range of each individual for whom such data were available. Data pertaining to age and sex of the skeletons from Tlajinga 33 and Tlailotlacan 6 are available in published form (Storey 1994; Spence \& Gamboa Cabezas 1999). Unpublished osteological data from La Ventilla 3 were kindly provided by Rubén Cabrera and Sergio Gómez, who directed excavations there. Sex and age determinations for the Axotlan skeletons were made by Anna C. Novotny, of Arizona State University, as part of the current project.

Females and males are relatively evenly represented in burials from each of the residential areas, although the number of male burials is slightly higher in all cases except Tlailotlacan 6 . This pattern, which is well-documented at Teotihuacan (e.g.

La Ventilla $3(n=93)$

Tlajinga $33(n=54)$

Tlailotlacan $6(n=10)$
Cid \& Torres 1999; González \& Salas 1999; Manzanilla et al. 1999; Sempowski 1994; Spence \& Gamboa Cabezas 1999; Storey \& Widmer 1999; Uruñuela \& Plunket 2007), indicates that females were buried outside of compounds more often than males. Such a practice may reflect a general pattern of patrilocal residential organization in Teotihuacan society, as proposed by Spence (1974) and Millon (1981, 208). Uruñuela \& Plunket $(2002,30 ; 2007,40)$ similarly link a preponderance of males in the burials of Late Formative Tetimpa, Puebla to patrilocality. They view this settlement as a rural precursor to the ritual and social structures that operated at early Teotihuacan (Uruñuela \& Plunket 2002, 34).

Beyond the prominence of males in compound burials, other factors that potentially bias the sample must be acknowledged. As Milner and colleagues (2000, 573) put it, a living population becomes a bioarchaeological sample through a selective process consisting of several stages. These include 'living

Table 1. Distribution of adults from each area by sex.

\begin{tabular}{|l|c|c|c|c|}
\hline Group & Females & Males & $\begin{array}{c}\text { Indeterminate } \\
\text { sex }\end{array}$ & Total \\
\hline Axotlan & 15 & 20 & 45 & 80 \\
\hline La Ventilla 3 & 22 & 25 & 46 & 93 \\
\hline Tlajinga 33 & 20 & 27 & 7 & 54 \\
\hline Tlailotlacan 6 & 6 & 2 & 2 & 10 \\
\hline Sex total & $\mathbf{6 0}$ & $\mathbf{7 3}$ & $\mathbf{9 5}$ & $\begin{array}{c}\text { Individuals } \\
(\boldsymbol{n}=\mathbf{2 3 7})\end{array}$ \\
\hline
\end{tabular}

Table 2. Age and sex of adults from each residential group.

\begin{tabular}{|c|c|c|c|c|c|c|}
\hline & $\begin{array}{c}\text { Adolescent } \\
(10-19)\end{array}$ & $\begin{array}{c}\text { Young adult } \\
(20-29)\end{array}$ & $\begin{array}{c}\text { Mid adult } \\
(30-39)\end{array}$ & $\begin{array}{c}\text { Aged adult } \\
(40+)\end{array}$ & $\begin{array}{c}\text { Indet. adult } \\
(20-40+)\end{array}$ & TOTAL \\
\hline \multicolumn{7}{|c|}{ Axotlan $(n=80)$} \\
\hline Female & 1 & 1 & 4 & 2 & 7 & 15 \\
\hline Male & 0 & 1 & 4 & 5 & 10 & 20 \\
\hline Indet & 0 & 2 & 5 & 3 & 35 & 45 \\
\hline TOTAL & 1 & 4 & 13 & 10 & 52 & 80 \\
\hline
\end{tabular}

\begin{tabular}{|l|c|c|c|c|c|c|}
\hline Female & 1 & 9 & 3 & 1 & 8 & $\mathbf{2 2}$ \\
\hline Male & 0 & 6 & 10 & 2 & 7 & $\mathbf{2 5}$ \\
\hline Indet & 0 & 4 & 0 & 0 & 42 & 46 \\
\hline TOTAL & $\mathbf{1}$ & $\mathbf{1 9}$ & $\mathbf{1 3}$ & $\mathbf{3}$ & 57 & $\mathbf{9 3}$ \\
\hline
\end{tabular}

\begin{tabular}{|l|c|c|c|c|c|c|}
\hline Female & 0 & 0 & 4 & 6 & 10 & $\mathbf{2 0}$ \\
\hline Male & 0 & 1 & 4 & 14 & 8 & $\mathbf{2 7}$ \\
\hline Indet & 0 & 0 & 1 & 0 & 6 & 7 \\
\hline TOTAL & $\mathbf{0}$ & $\mathbf{1}$ & $\mathbf{9}$ & $\mathbf{2 0}$ & $\mathbf{2 4}$ & $\mathbf{5 4}$ \\
\hline
\end{tabular}

\begin{tabular}{|l|l|l|l|l|l|c|}
\hline Female & 0 & 0 & 0 & 1 & 5 & $\mathbf{6}$ \\
\hline Male & 0 & 0 & 0 & 0 & 2 & 2 \\
\hline Indet & 0 & 0 & 0 & 0 & 2 & 2 \\
\hline TOTAL & $\mathbf{0}$ & $\mathbf{0}$ & $\mathbf{0}$ & $\mathbf{1}$ & $\mathbf{9}$ & $\mathbf{1 0}$ \\
\hline
\end{tabular}


$\rightarrow$ dead $\rightarrow$ buried $\rightarrow$ preserved $\rightarrow$ found $\rightarrow$ saved', and there is potential for a sample to become biased at any point in this chain of natural, cultural and archaeological events. The most significant problem with the intramural burial data at Teotihuacan is that they are not representative of the full range of practices employed for dealing with human remains. Basically, burials within Teotihuacan's compounds are too few to account for the entire population that occupied these structures (Uruñuela \& Plunket 2002, 30). Sempowski (1999) has calculated, for example, that each compound occupied continuously for 400 years should yield 1000 to 1600 skeletons. This estimate is not met by the current data, indicating that some people were likely buried away from the compounds and that others simply were not recovered via excavation. The former probably accounts for most missing burials, as intramural space was not unlimited.

Importantly, the fact that individuals of both sexes and all ages are represented in compound burials indicates that these burials likely comprised familial groups, rather than some other subset of society (Howell \& Kintigh 2004). The current data indicate that burial in or near compounds was an important ritual practice and may have been the most common method of disposing of the dead (Spence 1994, 339). Moreover, the presence of males and females facilitates consideration of patterned differences in mortuary rituals among Teotihuacan's residential groups that relate to gender. Therefore, the current data, while limited, are appropriate for this investigation of intrasocietal variation in domestic mortuary practices associated with male and female individuals.

I apply contingency analyses, particularly Fisher's exact test ${ }^{2}$, to evaluate correspondence between categorical variables and to determine whether null hypotheses can be rejected (Shennan 1997). In all analyses the null hypothesis is that the variables being evaluated are independent. The probability level ( $p$ value) for rejecting the null hypothesis is generally set at 0.05 . This level is arbitrary and, as Cowgill (2005) stresses, should not be viewed as a statistical talisman requiring the analyst to disregard slightly greater probability levels. Therefore, probability levels greater than 0.05 are reported in cases where it seems unlikely that the variables considered are independent. In these cases, results are presented in histograms or tables and arguments for their significance are based on informed consideration of quantitative and qualitative aspects of the data.

For some analyses, the number of cases was too low to apply contingency tests. For example, Tlailotlacan 6 is omitted from some analyses owing to the small sample size of males and females represented in the burials from this compound. I incorporate this residential area into qualitative and quantitative comparisons wherever possible, however, because it is an important example of ritual and social variation.

\section{Gender and mortuary material culture}

Archaeologists have often turned to grave-good quantity as a measure of the relative social status of individuals; this processual approach to mortuary analysis was pioneered by Saxe (1970) and Binford (1971). Sempowski (1994) applied this framework at Teotihuacan to investigate status differences within the general population, including general inequality between females and males. Sempowski (1994, 260-61) found very few manifest distinctions in the kinds of offerings associated with males and females. Nevertheless, she concluded, based on a higher proportion of females who either lacked or had fewer grave goods, that gender was a factor in social inequality:

Gender is [a] social principle which one expects to find as a basis for social differentiation in most societies ... Emerging from these observations, then, is the rather predictable implication that males held social positions of relatively greater importance at Teotihuacan than did females.

Due to limitations of the data, Sempowski's conclusions about the greater importance of males than females were based primarily on burials from one residential compound, La Ventilla B, and extrapolated to Teotihuacan society on the whole. Her assertion of lower female status at Teotihuacan neglects her own shrewd observation that qualitative distinctions in the burials of males and females were remarkably elusive. De Lucia $(2008,26)$ observes that Sempowski's conclusions resist the actual data and are firmly based in an a priori assumption that females have lower status than males in complex societies. As De Lucia $(2008,17)$ notes, anthropologists have traditionally viewed gender hierarchy as a universal condition of states, although they have debated the underlying reasons for and trajectories of gender inequity (also see Silverblatt 1988).

Despite her conclusion that males held positions of greater consequence than did females at Teotihuacan, Sempowski $(1994,261)$ explicitly suggested that a male bias may not have applied to all social groups. The research presented here responds to Sempowski's call for the analysis of a larger sample representing several distinct residential locations. Results indicate that females from every area investigated lacked 


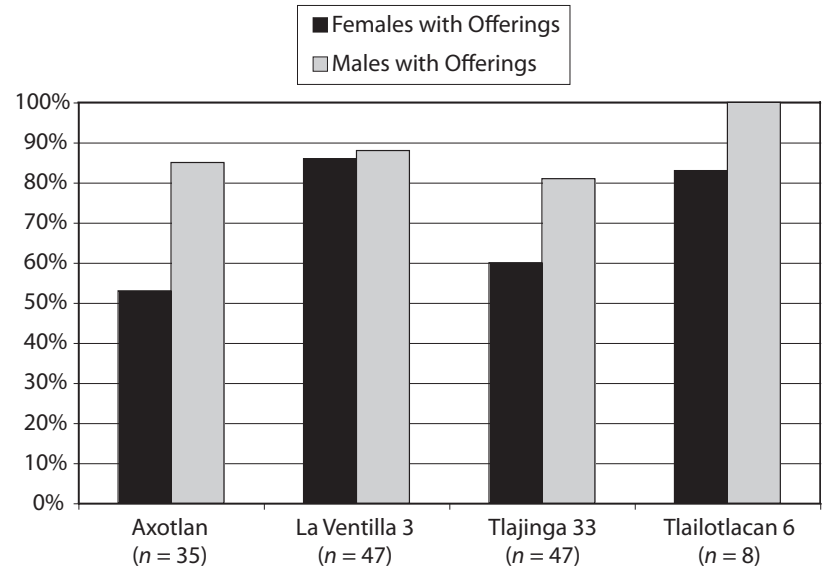

Figure 4. Percent of adult males and females at each residential area whose burials included grave goods.

Table 3. Contingency table comparing females and males from all areas in terms of the presence or absence of grave goods.

\begin{tabular}{|l|c|c|}
\cline { 2 - 3 } \multicolumn{1}{c|}{} & Females & Males \\
\hline Grave goods absent & 20 & 11 \\
\hline Grave goods present & 43 & 63 \\
\hline
\end{tabular}

Table 4. Contingency table comparing females at Axotlan and La Ventilla 3 in terms of the presence or absence of grave goods.

\begin{tabular}{|l|c|c|}
\cline { 2 - 3 } \multicolumn{1}{c|}{} & Axotlan & La Ventilla 3 \\
\hline Grave goods absent & 7 & 3 \\
\hline Grave goods present & 8 & 19 \\
\hline
\end{tabular}

Table 5. Mean number of objects with females and males at each site.

\begin{tabular}{|l|c|c|}
\cline { 2 - 3 } \multicolumn{1}{c|}{} & Females & Males \\
\hline Axotlan $(n=35)$ & 12 & 19 \\
\hline La Ventilla 3 $(n=47)$ & 21 & 22 \\
\hline Tlajinga 33 $(n=47)$ & 13 & 18 \\
\hline Tlailotlacan 6 $(n=8)$ & 7 & 4 \\
\hline
\end{tabular}

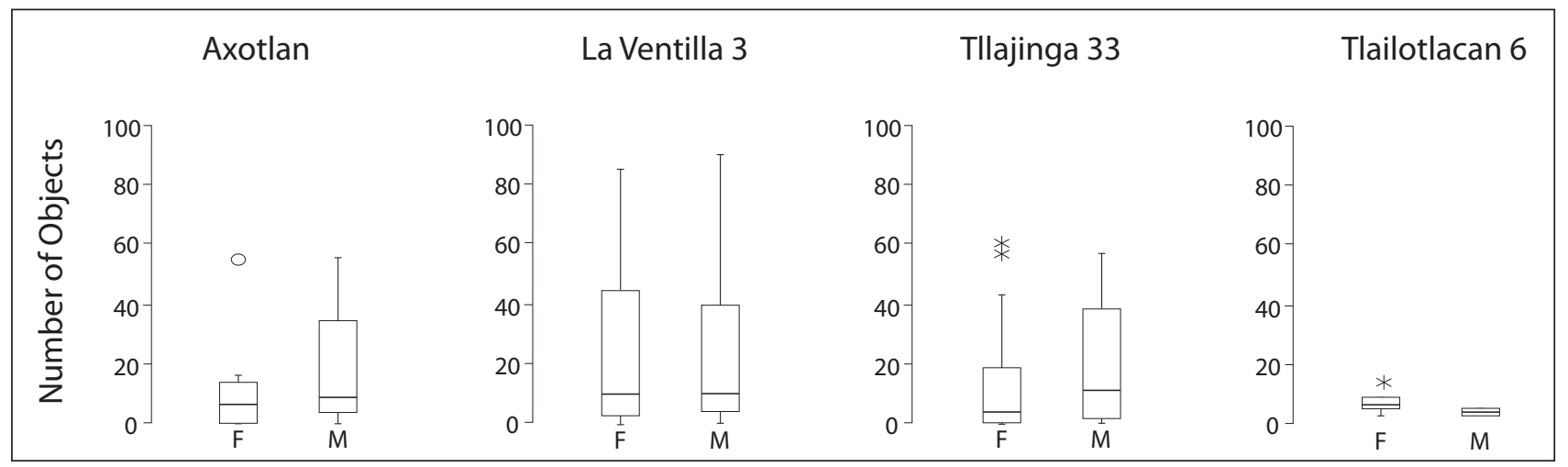

Figure 5. Comparison among sites of numbers of grave goods placed with adult females and males, respectively. Asterisks and ovals indicate outliers. One outlier from T33 (T33.57.1) was omitted from these analyses; this adult male had 4016 objects, including thousands of olivella beads.

burial offerings more often than did males (Fig. 4). My interpretations of this pattern, however, diverge significantly from Sempowski's suggestion that females were less valued than males in Teotihuacan society. Attempts to compare the status, writ large, of males and females in a complex, multi-ethnic society such as Teotihuacan are misguided. They neglect to consider the cultural diversity that characterizes such societies and ignore a range of factors affecting social status that may or may not intersect with gender.

When the burials from all areas in this study are combined and compared, as in Sempowski's approach, the difference between males and females in terms of the presence or absence of grave goods is statistically significant (Table 3). Males appear more likely in general to have been buried with durable offerings. Such a broad comparison, however, seriously obscures marked variation among the residential groups and impedes a more accurate understanding of Teotihuacan social structure.

More striking than the difference between males and females in general is the difference among the areas in the treatment of males and females (Fig. 4). At Axotlan, roughly half of females were buried with offerings, compared to 85 per cent of males. In striking contrast, females and males at La Ventilla 3 were equally likely to have grave goods; 86 per cent of women and 88 per cent of men in this group were buried with offerings. The difference between Axotlan and La Ventilla 3 in the proportions of women buried with grave goods is significant according to a Fisher's exact test, which yields a $p$ value of 0.056 (Table 4). Therefore, a pattern of material disparity in the burials of men and women evidently existed within some residential groups (e.g. Axotlan) but not others (e.g. La Ventilla 3). 
Variation among residential groups is also apparent with respect to the quantities of objects associated with females and males. Table 5 provides the mean numbers of objects buried with males and females within each residential group and box plots in Figure 5 show the range of numbers of grave goods associated with each sex. Clearly, males and females at La Ventilla 3 were buried with comparable amounts of grave goods. In contrast, females tended to have more grave goods than males at Tlailotlacan 6, a point that Spence $(2002,58)$ emphasizes. At Axotlan and Tlajinga 33, females frequently had fewer grave goods than males, suggesting that a gender dichotomy was perpetuated within these two residential groups.

In a Saxe (1970)-Binford (1971) approach, lower quantities or a lack of grave goods is generally attributed to lower social status. If this assessment is correct, then females at Axotlan and Tlajinga 33 would appear to have had lower status than males. However, such an inference is wholly unsatisfactory, as it fails to provide information about the activities and social roles of females and males within these groups. Moreover, there may be reasons completely unrelated to the concept of 'status' that offerings were either lacking or fewer in number in the graves of some individuals. The circumstances of death and the particular ritual and social roles of individuals during life frequently factor in the use of offerings and other aspects of mortuary ritual (Carr 1995). Materials placed within burials serve a range of purposes and have diverse meanings in the context of funerary rites. Some are valued possessions of the deceased or family heirlooms; others are expediently made or acquired for the performance of funerary rites, having no practical connection to the deceased during his or her life (Clayton 2009, 182-5).

For these reasons, qualitative differences in the materials and bodily treatments associated with females and males must be carefully considered in efforts to comprehend gender arrangements and the relative valuation of females and males at Teotihuacan. Gender-based inequity may have operated within Teotihuacan society or subsets thereof, but it cannot be ascertained based on quantities of grave goods alone. Before moving to a discussion of specific grave goods and bodily treatments, it is useful to consider what is known about Mesoamerican concepts of gender as well as the potential pathways to social power and prestige available to males and females.

Ethnographic and ethnohistoric research on Mesoamerican societies indicates that male and female categories were conceptualized as distinct but complementary and that each was essential to ensuring order and propriety in the world. The relationship of male to female was not overtly hierarchical in Postclassic Mesoamerican societies (Hendon 1999, 261). Evidence from sources such as the Codex Mendoza (vol. 3, 57v-60r) illustrates a complementary division of male and female activities. Girls learned to spin and weave; boys learned to fish, for example. These and a wide range of other activities and behaviours were the means by which gender was culturally inscribed on sexually-differing bodies. Joyce (2000) has referred to the process of developing gendered, decorous adults from the raw material of children in Aztec society as 'girling the girl and boying the boy' (also see Butler 1993, 7-8). Distinctions in activities, tasks and arenas of social interaction undoubtedly demarcated gender in individuals at Teotihuacan as well, although the particular activities were culturally specific to Teotihuacan society. ${ }^{3}$

Drawing from the work of Ortner \& Whitehead (1981), Hendon $(1999,258)$ proposed that gendered realms of behaviour constitute 'prestige structures', which entail differences in power. Power may be defined as 'that aspect of social relations that marks the relative equality of ... actors' (Adams 1975, 9-10). Hendon $(1999,259)$ emphasized the concomitant operation of a multiplicity of prestige structures, which inhere in diverse economic, religious, and political contexts. At Teotihuacan, prestige structures likely varied among residential groups, as ethnically diverse social units often involved in particular economic activities (Millon 1973). Prestige structures operating within particular groups likely related to a range of factors, including social status, political and religious affiliations, ethnicity, and economic organization.

Lapidary work at La Ventilla 3 is one example of a possible prestige structure that operated within this group. Many residents of La Ventilla 3 evidently engaged in lapidary activities (Gómez Chávez 2000), which may have constituted a significant path to prestige in the context of social and economic networks in which this group participated. Worked and unworked obsidian, chert, shell, greenstone, amethyst quartz, quartzite, travertine and mineral pigments were interred with both males and females at La Ventilla 3. This suggests that lapidary work provided opportunities to both sexes for social distinction.

If economic activities provided access to social prestige, why, then, were females and males at Axotlan and Tlajinga 33 not treated equally at death? The activities they engaged in may have been more rigidly gendered, but this would not, in itself, generate inequality, since distinct realms of behaviour can be complementary and of equal value. It has been sug- 
gested that the degree of control individuals have over the products of their labour affects prestige structures associated with economic activities (Brumfiel 1991; Hendon 1999). When the state controls production to a greater degree, social prestige associated with labour activities may diminish. At Teotihuacan, labour among residential groups may have been organized differently, perhaps depending on the nature of production activities and the economic integration of the group with the state. This variation is likely to affect the prestige structures operating among residential groups.

State administration and control aside, economic activities were, perhaps, not the primary source of relative prestige among individuals within some houses, and other arenas of social life may have taken precedence. Perhaps gendered divisions of action within these groups, whether economic or social, made available to males avenues to prestige that were not as accessible to women and vice versa. It is possible, for example, that the durable artefacts more frequently found in the burials of men than women represent prestige structures associated with masculine economic and social activities. The prestige structures of women within these groups, on the other hand, are perhaps not reflected in non-perishable burial offerings.

\section{Material variation and intrasocietal gender diversity}

Qualitative variation in the materials associated with individuals in burial brings into greater relief the activities of females and males and provides clues as to the degree to which gendered social roles either overlapped or were sharply divided. As Brumfiel $(2006,39)$ asserts, the persistent association of some artefact classes with women or men implies a gendered division of activities or at least the ideology of such a division.

Results of this comparative investigation suggest that gender categories were important in delineating social roles and daily activities in the context of some residential groups, but not as relevant within other groups. As discussed above, rural Axotlan exhibits the most conspicuous disparities between females and males in the presence and quantity of grave goods. This pattern extends to qualitative differences in the mortuary material culture associated with males and females. Care must be taken not to automatically assume that these differences were value-laden, implying the higher social importance of one sex over the other. It is reasonable to infer, however, that

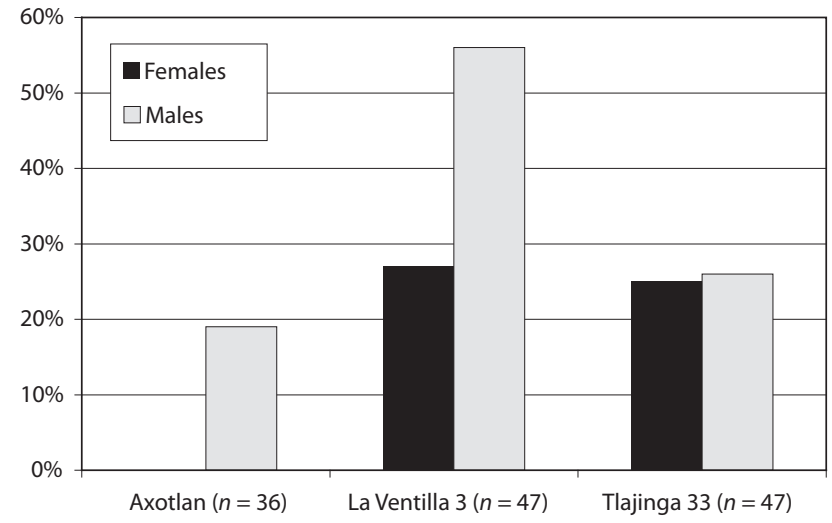

Figure 6. Percent of female and male adults at each residential area whose burials included obsidian artefacts.

females and males at Axotlan engaged in differing social, economic, and ritual activities in the context of their domestic groups and that the prestige structures available to them differed. In contrast, there seems to have been a great degree of overlap in the activities of males and females within the urban residential groups. Below, I discuss the use of several material categories in the burials of males and females among the groups, focusing on the implications of these patterns for the organization of gender roles.

I have pointed out that men and women at La Ventilla 3 evidently both participated in lapidary craft production, based on the presence of lapidary materials in the burials of both males and females. Patterns in the use of other materials as grave goods also point to heterogeneous gender structures across Teotihuacan society. The use of obsidian artefacts as burial accoutrements is an example.

Obsidian objects such as points, darts, bifaces and prismatic blades were used as burial offerings within all residential groups. Prismatic blades were the most frequent obsidian object in mortuary contexts (a combined total of 1275 blades occurred in burials from all areas). Prismatic blade cores were prevalent in the general assemblages of La Ventilla 3 and Tlajinga 33 , where lithic evidence suggests that residents were making prismatic blades and other tools (Gómez Chávez 2000; Spence 1987, 433). Interestingly, only residents of La Ventilla 3 utilized blade cores as burial offerings (Clayton 2009), suggesting that this ritual practice was meaningful to this group but not to residents of Tlajinga 33.

A gendered association of obsidian artefacts is suggested by the data, but this pattern varies among residential areas, with particularly striking differences between rural Axotlan and the urban compounds of La Ventilla 3 and Tlajinga 33. Figure 6 shows the 
percentage of males and females from each area whose burials included a range of obsidian artefacts, with prismatic blades comprising the vast majority of these objects. Obsidian occurred less frequently in the burials of Axotlan than in the urban areas in general. It is striking, however, that none of the adults determined to be female at Axotlan were buried with obsidian objects of any kind, while almost 20 per cent of males were buried with obsidian. ${ }^{4}$ This contrasts starkly with Tlajinga 33, where about 25 per cent each of males and females were buried with prismatic obsidian blades and other forms, including darts and flakes. Obsidian blades may have had a male association at La Ventilla 3, where they occurred in 56 per cent of the burials of men, compared to 27 per cent of the burials of women. Prismatic blade cores also occurred more frequently in the burials of males ( 20 per cent) than females (5 per cent) at La Ventilla 3. Of the residential areas investigated, however, Axotlan is the only one where obsidian may have been exclusively associated with males in burial. This implies a strong association between obsidian objects as accoutrements to mortuary ritual and masculine-gendered activities within this group.

The use of obsidian objects as grave goods may relate to whether a residential group either engaged in obsidian tool production or acquired finished products for use through a market system or exchange ties. This difference is likely to have significantly shaped the meaning of obsidian objects as burial offerings. Specifically, obsidian artefacts in some burials may represent made objects that figured in the economic livelihood of deceased persons. Alternatively, they may have been used objects, reflecting myriad activities ranging from bodily grooming, hunting, rituals involving cutting or battle.

Unlike La Ventilla 3 and Tlajinga 33, where residents produced obsidian objects such as blades, there is no clear evidence that such tools were being made at Axotlan, where obsidian artefacts were exclusively associated with males in burial. Rather, residents of Axotlan likely obtained blades and other tools through exchange relations with Teotihuacan or other settlements in the Basin of Mexico. Within the urban obsidian-knapping compounds, neither blades nor any other obsidian artefacts appear to have associated exclusively with either males or females.

Some kinds of ceramic vessels also associated with either females or males, although these associations were rarely exclusive and likely reflect tendencies, rather than absolute rules, of women and men to occupy particular social roles. The burials of Axotlan exhibit the most conspicuous differences between the
Table 6. Percentage of females and males at Axotlan buried with each object type.

\begin{tabular}{|l|c|c|}
\hline Object category & Female $(\boldsymbol{n}=\mathbf{1 5})$ & Male $(\boldsymbol{n}=\mathbf{2 1})$ \\
\hline composite censer & $6.7 \%$ & - \\
\hline cylindrical vase & - & $14.3 \%$ \\
\hline florero & - & $9.5 \%$ \\
\hline mini bundle & - & $4.8 \%$ \\
\hline mini florero & - & $9.5 \%$ \\
\hline mini grinding set & - & $4.8 \%$ \\
\hline mini jars & - & $4.8 \%$ \\
\hline mini tapaplato & - & $4.8 \%$ \\
\hline outcurving bowl & - & $14.3 \%$ \\
\hline punctated tecomate & - & $9.5 \%$ \\
\hline slate & - & $14.3 \%$ \\
\hline vasito (miniature) & - & $9.5 \%$ \\
\hline
\end{tabular}

sexes with respect to the use of ceramics, with some associations that were possibly exclusive.

Table 6 provides the number of females and males at Axotlan who were buried with a range of object categories and indicates that some objects may have strongly associated with males. ${ }^{5}$ These include cylindrical vases, floreros, outcurving bowls, punctated tecomates, vasitos and several kinds of miniatures (see Clayton 2009 for descriptions of these forms). These objects, many of which were likely used primarily in ritual contexts, were not found with any individuals determined to be female at Axotlan.

The association of a range of ceremonial objects with males in burial suggests that particular ritual activities were masculine-gendered domains of action at Axotlan. This pattern may bear on social organization at the settlement and its relationship with Teotihuacan, since all of these objects had counterparts at the urban center. The use of ritually important objects with males suggests that males at Axotlan may have been more closely tied to the urban population than females generally were. Perhaps Axotlan was structured in part on the practice of Teotihuacan-born males migrating to this rural settlement and marrying females from Axotlan or surrounding areas. If this were generally the case, however, there were notable exceptions. For example, the burial of two aged females (Burial AF1.135) contained a composite censer and a San Martín Orange vessel, likely produced in a Teotihuacan workshop (see Sullivan 2006). Composite censers are elaborate objects that are considered to be hallmarks of Teotihuacan material culture (Manzanilla 2002; Pasztory 1997). They are ubiquitous among urban compounds, testifying to their widespread significance, but they are few in number within each individual compound (Cowgill 1997, 142). This suggests that they were used by ritual specialists, perhaps in contexts in which many or all compound residents 
Table 7. Percentage of females and males at La Ventilla 3 buried with each object type.

\begin{tabular}{|l|c|c|}
\hline Object category & Female $(\boldsymbol{n}=\mathbf{2 2})$ & Male $(\boldsymbol{n}=\mathbf{2 5})$ \\
\hline bone tool & $18.2 \%$ & $12.0 \%$ \\
\hline censer adorno & $4.5 \%$ & $8.0 \%$ \\
\hline chert tool & - & $16.0 \%$ \\
\hline cylindrical vase & $27.3 \%$ & $28.0 \%$ \\
\hline greenstone object & - & $16.0 \%$ \\
\hline grinding stone & $4.5 \%$ & - \\
\hline miniature (any) & $9.1 \%$ & $20.0 \%$ \\
\hline outcurving bowl & $13.6 \%$ & $16.0 \%$ \\
\hline shell bead & $9.1 \%$ & $20.0 \%$ \\
\hline slate fragment & $18.2 \%$ & $40.0 \%$ \\
\hline
\end{tabular}

Table 8. Percentage of females and males at Tlajinga 33 buried with each object type.

\begin{tabular}{|l|c|c|}
\hline Object category & Female $(\boldsymbol{n}=\mathbf{2 0})$ & Male $(\boldsymbol{n}=\mathbf{2 7})$ \\
\hline bone needle & $5.0 \%$ & - \\
\hline cylindrical vase & - & $3.7 \%$ \\
\hline florero & - & $3.7 \%$ \\
\hline grinding stones & $5.0 \%$ & - \\
\hline outcurving bowl & $5.0 \%$ & $11.1 \%$ \\
\hline slate fragment & $5.0 \%$ & $3.7 \%$ \\
\hline
\end{tabular}

participated. Composite censers outside of urban Teotihuacan very likely indicate social or ideological connections to Teotihuacan's population and its institutions. The association of a composite censer with females at Axotlan suggests that women there were also socially linked with Teotihuacan, and that women might have migrated from the city to Axotlan. As well, the fact that the only known composite censer at Axotlan was buried with aged women suggests that females may have had particular roles as ritual specialists at this settlement.

Unlike Axotlan, very few objects at La Ventilla 3 were recovered exclusively from the burials of either females or males (Table 7), although some material categories, such as chert tools and greenstone objects, may have associated more often with males. Mortuary data from La Ventilla 3 suggest that this group differed significantly from Axotlan in terms of gender roles. The use of cylindrical vases (Fig. 7) as grave goods provides a case in point. These vessels are among the most widely recognized aspects of Teotihuacan material culture (Conides 1997; Rattray 2001; Sempowski 1992). They are often intricately decorated, prompting some to consider them as 'luxury goods' associated with high status (e.g. Sempowski 1992). They occur most frequently in burials with high quantities of offerings (Clayton 2009, 197).

Cylindrical vases were not associated with any individuals determined to be female at Axotlan, but at La Ventilla 3 they were equally likely to be buried

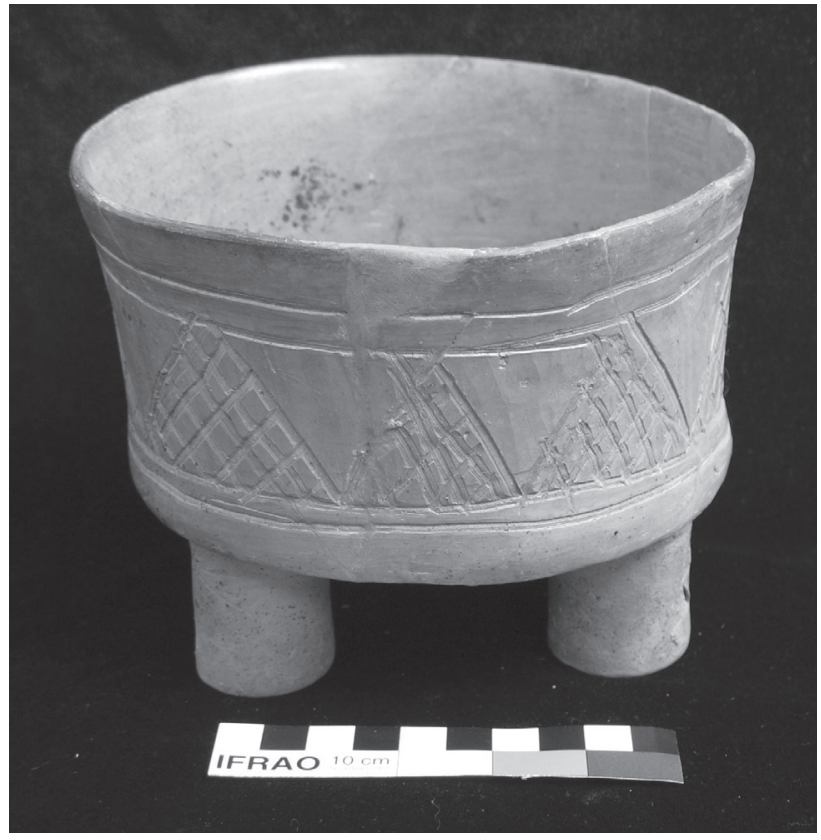

Figure 7. Cylindrical vase from a La Ventilla 3 burial.

with females and males. This suggests that in the urban group males and females alike participated in activities involving these vessels, but that this was not true of rural Axotlan. The relatively loose association of artefact classes with either females or males at La Ventilla 3 suggests that gender was not very important in structuring activities within this group. In sum, gender roles appear to have been less strictly delineated at La Ventilla 3 than they were at rural Axotlan.

Mortuary data from Tlajinga 33 suggest that the delineation of activities by male or female gender categories was blurred within this group also, as materials were rarely exclusively buried with either men or women. I have mentioned that obsidian artefacts were equally likely to accompany females and males in burial at Tlajinga 33. In fact, the largest and most diverse array of green, gray, and red obsidian objects was associated with a female (Burial 15). This deposit of 44 obsidian artefacts included flakes, bifaces, several very narrow blades, a semi-circle eccentric, and two darts.

There are no outstanding differences in the kinds of objects placed with males and females at Tlajinga 33 (Table 8), although some patterns may point to commonalities among all residential groups. For example, grinding stones were associated with females at both Tlajinga 33 and at La Ventilla 3. This pattern must be recognized as tentative, however, since the frequency of groundstone artefacts in burials is low.

The small sample of adult burials from Tlailot- 
lacan 6 (six females, two males, and two adults of indeterminate sex) makes it difficult to identify gender-related differences in the mortuary practices of this group. Spence and colleagues (Spence \& Gamboa Cabezas 1999, 195; Spence 2002, 58; Spence et al. 2005, $167)$ assert that there was relative equality among females and males at Tlailotlacan, and the mortuary data support this assertion. Only a female in this sample was associated with an obsidian point, which may have been an implement or symbol of hunting or warfare. This constitutes additional evidence that obsidian artefacts were generally associated with both females and males in urban contexts, in stark contrast to rural Axotlan. Two females at Tlailotlacan 6 were buried with greenstone beads, which were socially valued in Mesoamerican societies (Lesure 1999, 36-48). A more rigorous evaluation of the use of material culture in funerary rites to delineate gender identities at Tlailotlacan 6 would require a larger sample of adults whose sex can be determined.

\section{Gender complementary in mortuary ritual: body position and orientation}

Although specific, emic beliefs associated with the arrangement of the body may not be accessed archaeologically, patterned associations between the positioning of the body and other variables, including sex, provide clues as to social significance. In this section I discuss the association between sex and body placement. I argue that, despite evident differences in gender roles, the residents of Axotlan and La Ventilla 3 espoused similar beliefs concerning the arrangement of female and male bodies in burial. Specifically, a mutually-recognized notion of gender complementarity is suggested by the tendency to orient males and females in opposite directions in burial contexts at Axotlan and La Ventilla 3. Tlajinga 33 and Tlailotlacan differed in this respect from Axotlan and La Ventilla 3 , in that they did not, evidently, express gender complementarity in body orientation or position.

\section{Body position}

When the residential groups are compared it becomes clear that they varied with respect to the positioning of females and males in primary burials (Fig. 8). The degree to which the groups differed is not consistent, however, and this finding is at least as significant as the general variation among groups. In particular, Axotlan and La Ventilla 3 share a strikingly similar 'position profile'. Males and females were buried in seated, dorsal or lateral positions in similar proportions in these two residential areas. This comparability
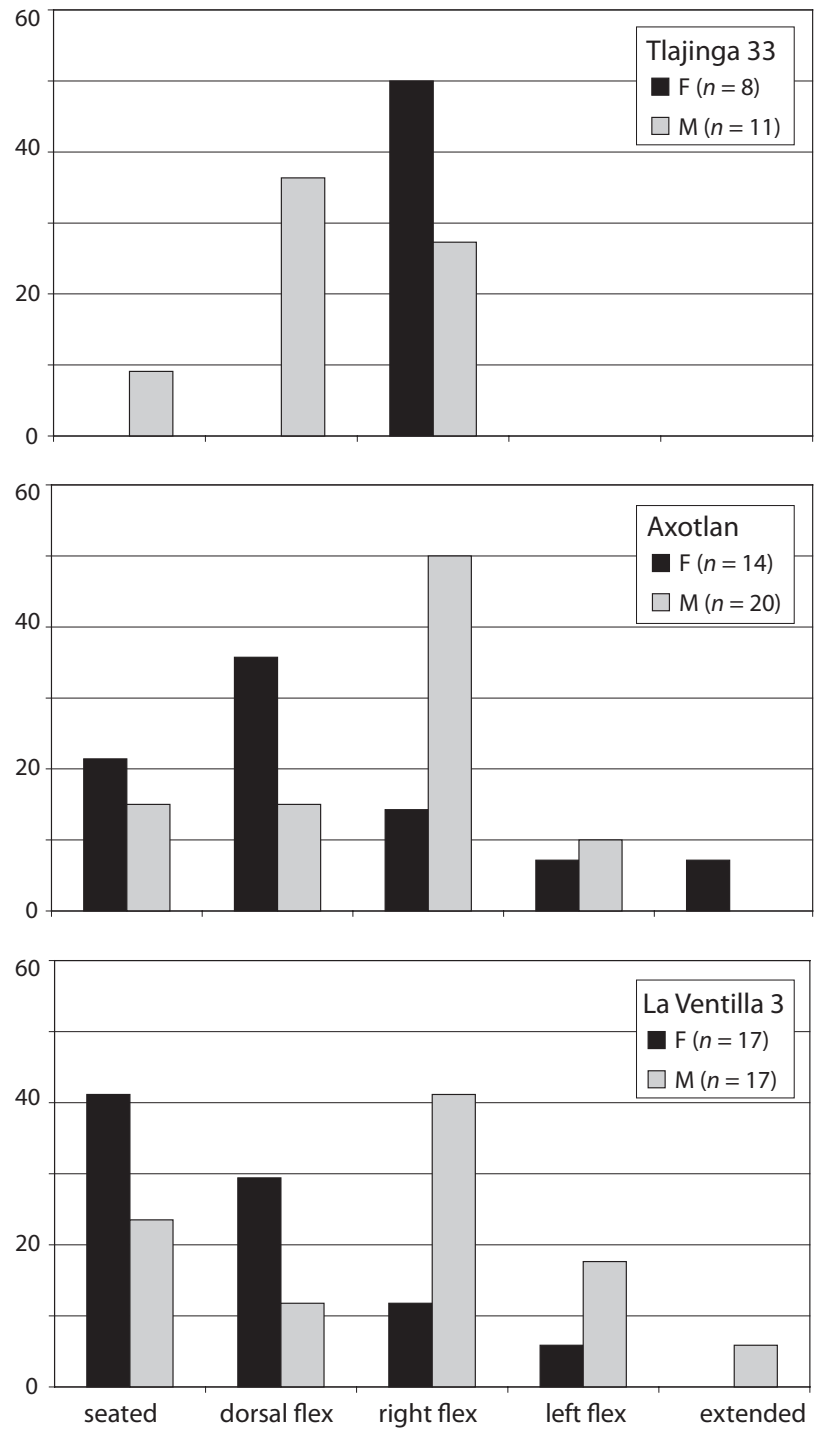

Figure 8. Body positions of males and females at each residential group, $y$ axis is percent scale (primary burials).

in body positioning indicates that shared aspects of ritual ideology guided mortuary behaviours within these residential groups. Specifically, they held similar beliefs concerning the proper arrangement of male and female bodies in burial.

Tlajinga 33 departs markedly from Axotlan and La Ventilla 3 in the positioning of females and males in primary burial. Half of females in this compound were placed on their right side, a position associated with males at Axotlan and La Ventilla 3. The pattern from Tlajinga 33 is tentative, since the number of primary burials containing adults whose sex could be determined is low for this compound. However, if it is meaningful, it suggests that residents of this 

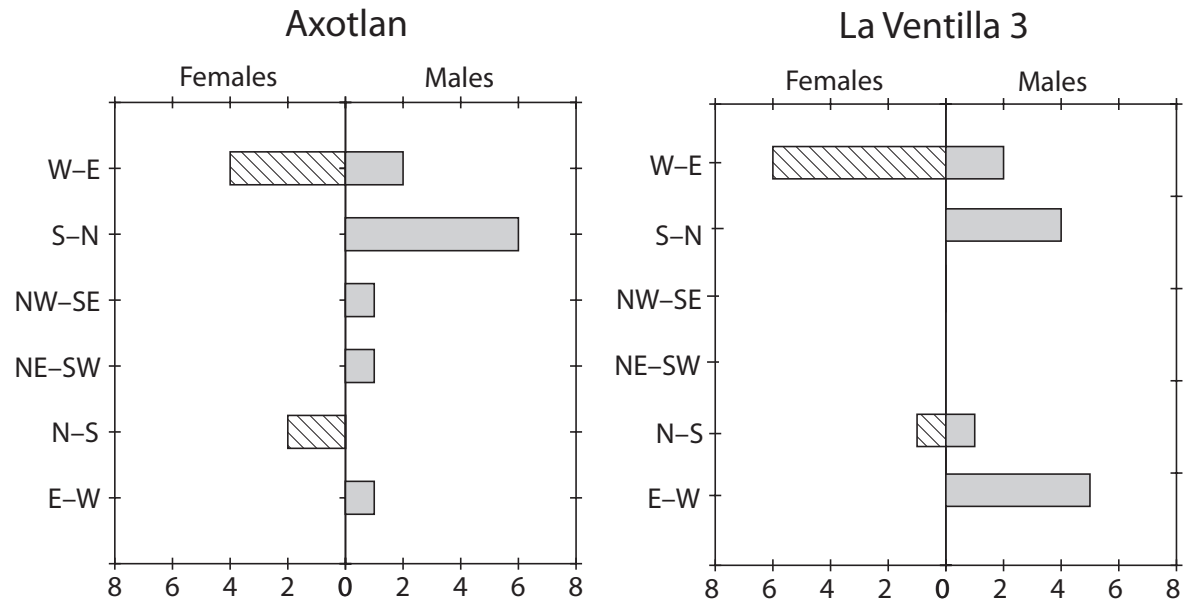

Tlajinga 33
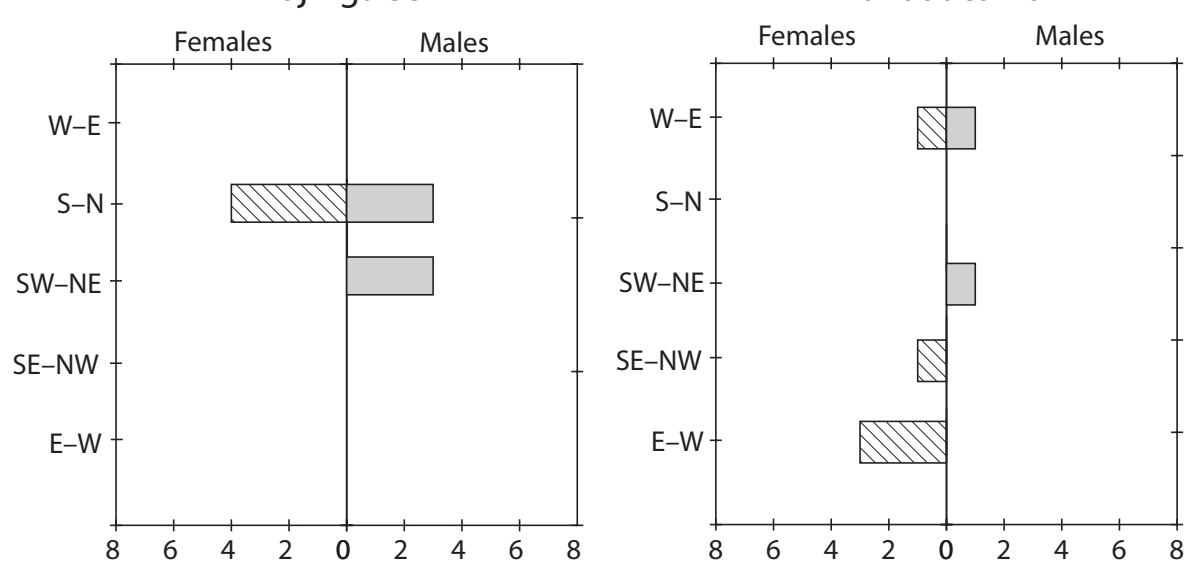

Figure 9. Head-to-foot orientation of females and males at each locale, including only individuals placed on their side or back in a primary context.

compound subscribed to differing beliefs concerning gender and body positioning in burial than did other residential groups. This finding highlights the distinct possibility that ideological notions of gender difference, and their ritual expression, varied considerably among Teotihuacan's social houses.

\section{Body orientation}

In addition to similarities with respect to body position, Axotlan and La Ventilla 3 were highly congruent in the cardinal orientation of male and female bodies. Residential groups were compared in terms of the orientation of males and females, focusing on cases in which the body was on its side or back (not seated, in which the head-to-foot orientation is vertical: see Sugiyama 2005). Residents of these two areas appear to have expressed a notion of gender complementarity of females and males in the head-to-foot arrangement of the body (Fig. 9). The pattern of orientation by sex resulting from this comparison is discernible only when the groups are compared. In other words, socio-spatial variation in body orientation would be obscured if burials from all locales were lumped together as 'representative' of Teotihuacan society. This illustrates the salience of domestic contexts in shaping ritual behaviours and social identities. Sempowski $(1994,141)$ noted that an east-west orientation was most frequent at Teotihuacan, followed by west-east; she did not, however, consider gendered differences in orientation.

At every residential area except Tlailotlacan 6, where the sample size is small, the orientation of males was more varied than that of females. At Axotlan and La Ventilla 3 there is a pattern of male-female directional opposition. Most females in these two groups were oriented west-east (head to west, feet to east), with a smaller proportion oriented north-south. The fact that this pattern is shared between the two 
residential groups strongly suggests that it is meaningful. Males in these two areas were most frequently oriented south-north and east-west. Females were never oriented this way at either Axotlan or La Ventilla 3 , at least within the current sample. The difference in orientation may relate to a variety of factors, such as the cause of death, the impact of gender on the destination of the soul or the social roles filled by individuals gendered male or female.

Orientation patterns at Tlajinga 33 and Tlailotlacan 6 differ markedly from those of Axotlan and La Ventilla 3. At Tlajinga 33, almost all adults were oriented south-north, with a few males leaning southwest-northeast (whether the latter represented a meaningful distinction is not clear). What stands out is the evident lack of gender complementarity in body orientation at Tlajinga 33. At Tlailotlacan 6, individuals were oriented in a pattern nearly opposite that of Axotlan and La Ventilla 3; females here were most frequently oriented east-west and males west-east. The sample from Tlailotlacan 6 is too small to draw conclusions about gender complementarity in orientation, although the data hint that such a notion might have inhered in the ritual ideology of this group.

Analyses of body orientation by sex and residential group indicate that beliefs concerning the proper arrangement of the deceased varied and that gender was a factor, at least among some groups, in this aspect of funerary ritual. Tlajinga 33 was particularly distinctive among the residential areas. In this compound, males and females were not directionally distinguished and south-north orientation was evidently meaningful. Axotlan and La Ventilla 3 , on the other hand, likely belonged to a subset of the population that shared aspects of ritual ideology concerning the use of position and orientation to mark gender difference.

\section{The implications of alternative gender discourses}

Intrasocietal diversity significantly contours the historical trajectories of ancient states and should, therefore, be a central concern in efforts to understand their development and decline. In this study gender is identified as a dimension of intrasocietal variation at Teotihuacan through the application of a theoretical framework that emphasizes the nested and contextual nature of identity. Results of this investigation reaffirm the fact that gender in a complex society such as Teotihuacan cannot be understood in terms of status hierarchy (Stockett 2005). Gender and other constructs of identity are most effectively investigated at scales that situate their development and expression within domestic groups and other relevant contexts of human interaction.

A significant finding is that gender ideologies constituted not only a dimension of distinction but also of affiliation among houses. Moreover, groups that evidently espoused similar ideological dispositions concerning gender were not necessarily spatially contiguous. For example, conventions associated with burying males and females at urban La Ventilla 3 were more congruent with those of rural Axotlan than with some urban groups (e.g. Tlajinga 33) in closer proximity. Specifically, the shared practice of orienting males and females in opposing directions indicates that these groups expressed, through body arrangement, mutually-recognized notions of gender difference. Ideas of masculine and feminine complementarity inhere in the worldviews of many Mesoamerican societies (Hendon 1999). Whether all or most of Teotihuacan's houses subscribed to this notion is not known, but it is evident that some residential groups, such as Tlajinga 33 and Tlailotlacan 6, did not express beliefs in gender complementarity through the directional orientation of the body; this was a prominent aspect of mortuary ritual only in particular houses.

Ethnicity is likely to have factored significantly in differences among residential groups with respect to gender arrangements and ideologies and to practices such as the placement of the body in burial. Tlailotlacan 6 is widely understood to have been part of a Zapotec enclave (Spence et al. 2005), so it is not surprising that distinctive ritual traditions were maintained there. However, Tlajinga 33 is perhaps a more intriguing example of the intermingling of ethnicity with other aspects of social identity within Teotihuacan society. White and colleagues (2004) assert, based on stable isotopic evidence, that a substantial number (perhaps more than a quarter) of the compound's residents were immigrants. Although much of the material culture at Tlajinga 33 is considered typical of Teotihuacan, there are also overt indications of the perpetuation of foreign ritual practices here. The most outstanding example is a West-Mexican-style shaft tomb within the compound (Storey 1992; White et al. 2004). Stable isotopic data similar to that generated for Tlajinga 33 are not available for other compounds considered to represent the mainstream population at Teotihuacan. As a result, it is unclear whether the presence of recent immigrants is unique to Tlajinga 33 or whether it was a widespread phenomenon among the general population. The current data support the latter hypothesis, as materials and practices understood as foreign to Teotihuacan are present in virtually every area that has been excavated. In sum, ethnic 
diversity seems to have been a characteristic feature of Teotihuacan's social landscape, with immigrants interlaced throughout the population. However, the degree to which ethnicity was manipulated as mode of social identification and distinction among residential groups is likely to have varied widely.

Multiscalar research on other early states in the Americas similarly demonstrates that ideological constructs and associated practices served both to delineate social groups and to forge affiliations across geographical distance. For example, Goldstein (2000) and Janusek \& Blom (2006) indicate that large, non-contiguous groups shared social identities that distinguished them from other such groups within Tiwanaku society. These identities were perpetuated through shared behaviours and material culture. Janusek \& Blom $(2006,236)$ describe these configurations as 'incomplete communities' and suggest that their connections might be effectively explored using the concept of heterarchy (Ehrenreich et al. 1995). Such an approach goes beyond reconstructing hierarchies to investigate distinct social groups that were neither ranked nor fully integrated. This concept has utility for Teotihuacan and other multiethnic Mesoamerican states that were characterized by the presence of, and interactions among, effectively equal but dissimilar components of the rural and urban population.

McCafferty's work at Postclassic Cholula exemplifies an appropriately nuanced approach to a multiethnic, complex society in that it avoids the use of an oversimplified elite-commoner heuristic dichotomy or hierarchical reconstruction. McCafferty $(2007,214)$ stresses that a great deal of diversity should be expected among commoners in multicultural urban settings:

Urban centers are defined by multiculturalism, and conceptualizations of Mesoamerican cities should incorporate this principle. The result ... is a postmodern cacophony of agency, as a multitude of social actors strategically manipulated their lives in a dialectical relationship with their cultural surroundings.

Ritual variation among residential groups at Teotihuacan testifies to the social and ideological diversity of its population. Some groups were affiliated, at least symbolically, through common adherence to certain beliefs and practices, reflecting the nested nature of identity. These groups likely participated in wider arenas of interaction (e.g. the exchange of marriage partners, economic transactions and political events) through which their mutual beliefs were reinforced. Other groups evidently eschewed certain beliefs and practices, either as acts of ideological resistance or because such practices were not meaningful for social relationships within the group. It is reasonable to speculate that ideological fissures such as these were potential sources of tension that may have factored in the eventual sociopolitical dissolution of Teotihuacan.

Despite the congruence between Axotlan and La Ventilla 3 in the arrangement of male and female bodies, these groups evidently differed considerably with respect to the social roles of women and men. Specifically, males and females at Axotlan seem to have engaged in differing sets of activities, based on the patterned association of artefacts with one sex or the other in burial. In contrast, sex does not appear to have been nearly as significant in structuring social roles and activities within the urban groups. The apparent disjuncture between ideology and daily life, as reflected in mortuary contexts, is due to the multifaceted and multi-referential nature of ritual acts.

Although I have opted to focus on gender, comparative analyses of mortuary practices associated with other facets of identity, such as age, also reveal marked socio-spatial variation. For example, individuals older than forty years of age at Axotlan were buried with some objects that were evidently exclusive to that age group (Clayton 2009). In contrast, age differences among adults do not seem to have been prominently expressed through the use of specific mortuary material culture within the urban groups considered in this investigation. A thorough treatment of heterogeneity with respect to age-related identities and ideologies is beyond the scope of this article and is discussed in detail elsewhere (Clayton 2009). It is clear, though, that the role of ideological diversity in shaping the social milieu of a complex society may be fruitfully approached in terms of several different axes of variation.

I have argued that likeness and difference in the mortuary conventions of discrete residential groups point to connections as well as distinctions among subsets of Teotihuacan society. Gender roles and ideologies were fundamentally shaped through social and ritual interactions situated within the context of domestic groups. None of the groups investigated were exactly alike with respect to the mortuary practices associated with males and females. Rather, multiple discourses pertaining to the roles of males and females and the meanings of gender difference operated in Teotihuacan society. The population of Teotihuacan constituted a mosaic of distinctive group identities that blended notions of ethnicity, class, occupation, religion and ancestral descent. These domains of identity did not neatly correspond to particular residential groups and they transcended rural and urban divisions. The degree of intrasocietal diversity present 
at Teotihuacan must have factored significantly in the administrative challenges and structural weaknesses of its sociopolitical institutions.

\section{Acknowledgements}

This research was supported by funding from The Foundation for the Advancement of Mesoamerican Studies, Incorporated and could not have gone forward without permissions and assistance from several individuals. I thank Rubén Cabrera Castro, Sergio Gómez Chávez, Raúl García Chávez, Michael W. Spence and Rebecca Storey for graciously sharing their data. It is my pleasure to acknowledge the crucial help I received from Anna Novotny, who analysed the skeletal material from Axotlan. Comments from three anonymous reviewers contributed significantly to the final version of this article. Finally, I am deeply grateful to George L. Cowgill, Barbara L. Stark and Keith W. Kintigh, who provided invaluable guidance during all phases of the research. Any errors are entirely my own.

$$
\begin{array}{r}
\text { Sarah C. Clayton } \\
\text { Department of Anthropology } \\
\text { University of Wisconsin } \\
5240 \text { W.H. Sewell Social Science Building } \\
1180 \text { Observatory Drive } \\
\text { Madison, WI 53706 } \\
\text { USA } \\
\text { Email: sclayton@wisc.edu }
\end{array}
$$

\section{Notes}

1. Intrasocietal variation in the mortuary practices associated with perinates and children is discussed at length in the author's dissertation (Clayton 2009).

2. Fisher's exact test is the preferred method when sample sizes are small (Agresti 1990), since Pearson's chi-square requires that expected cell counts be greater than five.

3. Weaving, which has been explored as a source of social prestige for Aztec women (Brumfiel 1991; 1996) may not have been a prominent activity among women at Teotihuacan; there is a paucity of archaeological evidence for weaving and spinning in the city, although bone awls and needles are frequent and suggest that the embellishment of textiles through sewing and embroidery was prevalent (Cabrera Cortés 2001).

4. About 10 per cent (5 of 51) individuals of unknown sex at Axotlan were buried with obsidian artefacts; it is possible that some of these were female. If obsidian artefacts were typically buried with females in this area, however, then it seems likely that at least one of the individuals determined to be female would have been associated with obsidian.

5. This tabulation includes only those individuals with whom grave goods could be specifically associated. Individuals from mixed contexts that included both sexes were omitted from analyses unless objects could be specifically attributed to a particular individual in the context. This was necessary for investigating patterns of association by sex.

\section{References}

Adams, R.N., 1975. Energy and Structure: a Theory of Social Power. Austin (TX): University of Texas Press.

Agresti, A., 1990. Categorical Data Analysis. New York (NY): Wiley.

Arnold, B., 2001. 'Sein and werden': gender as process in mortuary ritual, in In Pursuit of Gender, eds. S.M. Nelson \& M. Rosen-Ayalon. New York (NY): Altamira Press, 239-56.

Arnold, B., 2006. Gender and archaeological mortuary analysis, in Handbook of Gender in Archaeology, ed. S.M. Nelson. Lanham (MD): Altamira Press, 137-70.

Bell, C.M., 1997. Ritual: Perspectives and Dimensions. New York (NY): Oxford University Press.

Binford, L., 1971. Mortuary practices: their study and potential, in Approaches to the Social Dimensions of Mortuary Practices, ed. J.A. Brown. (Memoirs 25.) Washington (DC): The Society for American Archaeology, 6-29.

Blackless, M., A. Charuvastra, A. Derryk, A. Fausto-Sterling, K. Lauzanne \& E. Lee, 2000. How sexually dimorphic are we? Review and synthesis. American Journal of Human Biology 12, 151-66.

Brumfiel, E.M., 1991. Weaving and cooking: women's production in Aztec Mexico, in Engendering Archaeology: Women and Prehistory, eds. J.M. Gero \& M.W. Conkey. Cambridge (MA): Blackwell Publishers, 224-54.

Brumfiel, E.M., 1992. Distinguished lecture in archeology: breaking and entering the ecosystem - gender, class, and faction steal the show. American Anthropologist 94, 551-67.

Brumfiel, E.M., 1996. Figurines and the Aztec state: testing the effectiveness of ideological domination, in Gender and Archaeology, ed. R. Wright. Philadelphia (PA): University of Pennsylvania Press, 143-66.

Brumfiel, E.M., 2001. Asking about Aztec gender: the historical and archaeological evidence, in Gender in Pre-Hispanic America, ed. C.F. Klein. Washington (DC): Dumbarton Oaks, 57-86.

Brumfiel, E.M., 2006. Methods in feminist and gender archaeology: a feeling for difference - and likeness, in Handbook of Gender Archaeology, ed. S.M. Nelson. Lanham (MD): Altamira Press, 31-58.

Butler, J., 1993. Bodies that Matter: on the Discursive Limits of Sex. London: Routledge.

Cabrera Cortés, M.O., 2001. Textile Production at Teotihuacan, Mexico. Unpublished Masters Thesis, Arizona State University.

Carr, C., 1995. Mortuary practices: their social, philosophicalreligious, circumstantial, and physical determinants. Journal of Archaeological Method and Theory 2, 105-200.

Chance, J., 2000. The noble house in colonial Puebla, Mexico: descent, inheritance, and the Nahua tradition. American Anthropologist 102, 485-502.

Charlton, T.H., 1991. The influence and legacy of Teoti- 
huacán on regional routes and urban planning, in Ancient Road Networks and Settlement Hierarchies in the New World, ed. C.D. Trombold. Cambridge: Cambridge University Press, 186-97.

Charlton, T.H., 2000. Urban Influences at Rural sites: Teotihuacán and its Near Hinterlands. Report submitted to the Foundation for the Advancement of Mesoamerican Studies (FAMSI). www.famsi.org.

Cid, R. \& L. Torres, 1999. Los entierros del occidente de la ciudad, in Prácticas Funerarias en la Ciudad de los Dioses: Los Enterramientos Humanos de la Antigua Teotihuacan, eds. L. Manzanilla \& C. Serrano. Mexico City: Instituto de Investigaciones Antropológicas, Universidad Nacional Autónoma de México, 285-344.

Clayton, S.C., 2005. Interregional relationships in Mesoamerica: interpreting Maya ceramics at Teotihuacan. Latin American Antiquity 16(4), 427-48.

Clayton, S.C., 2008. Measuring the Long Arm of the State: Teotihuacan's Relations in the Basin of Mexico. Paper presented at the 73rd meeting of the Society for American Archaeology, Vancouver (BC).

Clayton, S.C., 2009. Ritual Diversity and Social Identities: a Study of Mortuary Behaviors at Teotihuacan, Mexico. Unpublished PhD dissertation, School of Human Evolution and Social Change, Arizona State University.

Cohen, A.P., 1985. The Symbolic Construction of Community. New York (NY): Tavistock Publications.

Conides, C.A., 1997. Social relations among potters in Teotihuacan, Mexico. Museum Anthropology 21(2), 39-54.

Conkey, M.W. \& J.M. Gero, 1991. Tensions, pluralities, and engendering archaeology: an introduction to women and prehistory, in Engendering Archaeology, eds. J.M. Gero \& M.W. Conkey. Oxford: Blackwell Publishers, 3-30.

Cowgill, G.L., 1997. State and society at Teotihuacan, Mexico. Annual Review of Anthropology 26, 129-61.

Cowgill G.L., 2005. Things to remember about statistics (whatever else you forget). SAA Archaeological Record $5,33-5$.

Cowgill, G.L., 2007. The urban organization of Teotihuacan, Mexico, in Settlement and Society: Essays Dedicated to Robert McCormick Adams, ed. E.C. Stone. Los Angeles (CA): Cotsen Institute of Archaeology, 261-95.

Cowgill, G.L., J.H. Altschul \& R.S. Sload, 1984. Spatial analysis of Teotihuacan: a Mesoamerican metropolis, in Intrasite Spatial Analysis in Archaeology, ed. H.J. Hietala. Cambridge: Cambridge University Press, 154-95.

Ehrenreich, R.M., C.L. Crumley \& J.E. Levy (eds.), 1995. Heterarchy and the Analysis of Complex Societies. (Archeological Papers 6.) Washington (DC): American Anthropological Association.

Fausto-Sterling, A., 2000. Sexing the Body: Gender Politics and the Construction of Sexuality. New York (NY): Basic Books.

García Chávez, R., L.M. Gamboa Cabezas \& N.Vélez Saldaña, 2004. Informe final de las actividades realizadas en el Predio de San Ignacio y La Loma, del poblado de Axotlan, Municipio de Cuautitlan Izcalli, Estado de México. Mexico City: Instituto Nacional de Antropología e Historia.
García Chávez, R., L.M. Gamboa Cabezas \& N.V. Vélez Saldaña, 2005. Excavaciones recientes en un sitio de la fase Tlamimilolpa en Cuautitlán Izcalli, Estado de México, in Arquitectura y Urbanismo: Pasado y Presente de los Espacios en Teotihuacan, eds. M.E. Ruiz Gallut \& J. Torres Peralta. Mexico City: Instituto Nacional de Antropología e Historia, 487-505.

Geller, P.L., 2005. Skeletal analysis and theoretical complications. World Archaeology 37(4), 597-609.

Geller, P.L., 2009. Identity and difference: complicating gender in Archaeology. Annual Review of Anthropology $38,65-81$.

Gillespie, S.D., 2000a. Beyond kinship: an introduction, in Beyond Kinship: Social and Material Reproduction in House Societies, eds. R.A. Joyce \& S.D. Gillespie. Philadelphia (PA): University of Pennsylvania Press, 1-22.

Gillespie, S.D., 2000b. Lévi-Strauss: maison and société à maisons, in Beyond Kinship: Social and Material Reproduction in House Societies, eds. R.A. Joyce \& S.D. Gillespie. Philadelphia (PA): University of Pennsylvania Press, 22-51.

Goldstein, P.S., 2000. Communities without borders: the vertical archipelago and diaspora communities in the southern Andes, in The Archaeology of Communities: a New World Perspective, eds. M.A. Canuto \& J. Yaeger. New York (NY): Routledge, 182-209.

Gómez Chávez, S., 1996. Unidades de producción artesanal y de residencia de Teotihuacan. Primeros resultados de las exploraciones del Frente 3 del Proyecto La Ventilla 92-94. Revista Mexicana de Estudios Antropológicos XLII, 31-47.

Gómez Chávez, S., 2000. La Ventilla: un Barrio de la Antigua Ciudad de Teotihuac $\alpha$ n. Unpublished PhD dissertation. Escuela Nacional de Antropología e Historia, México City.

González, L.A. \& M.E. Salas, 1999. Los entierros del centro político-religioso y de las periferia de Teotihuacan de la Temporada 1980-1982, in Prácticas funerarias en la Ciudad de los Dioses: los enterramientos humanos de la antigua Teotihuacan, eds. L. Manzanilla \& C. Serrano. México City: Instituto de Investigaciones Antropológicas, Universidad Nacional Autónoma de México, 219-46.

Hays-Gilpin, K., 2004. Ambiguous Images: Gender and Rock Art. Walnut Creek (CA): Altamira Press.

Headrick, A., 2007. The Teotihuacan Trinity: the Sociopolitical Structure of an Ancient Mesoamerican City. Austin (TX): University of Texas Press.

Hendon, J.A., 1999. Multiple sources of prestige and the social evaluation of women in prehispanic Mesoamerica, in Material Symbols: Culture and Economy in Prehistory, ed. J.E. Robb. Carbondale (IL): Center for Archaeological Investigations, Southern Illinois University.

Hendon, J.A., 2007. The engendered household, in Women in Antiquity: Theoretical Aproaches to Gender and Archaeo$\log y$, ed. S.M. Nelson. Lanham (MD): Altamira Press, 141-68.

Howell, T.L. \& K.W. Kintigh, 2004. Archaeological identifica- 
tion of kin groups using mortuary and biological data: an example from the American southwest. American Antiquity 61, 537-54.

Janusek, J.W. \& D.E. Blom, 2006. Identifying Tiwanaku urban populations: style, identity, and ceremony in Andean cities, in Urbanism in the Preindustrial World: Cross-cultural Approaches, ed. G.R. Storey. Tuscaloosa (AL): University of Alabama Press, 233-51.

Joyce, R.A., 2000. Girling the girl and boying the boy: the production of adulthood in ancient Mesoamerica. World Archaeology 31, 473-83.

Joyce, R.A., 2001. Burying the dead at Tlatilco: social memory and social identities, in Social Memory, Identity, and Death: Anthropological Perspectives on Mortuary Rituals, ed. M.S. Chesson. (Archeological Papers 10.) Washington (DC): American Anthropological Association, 12-26.

Joyce, R.A., 2008. Ancient Bodies, Ancient Lives: Sex, Gender, and Archaeology. New York (NY): Thames \& Hudson.

Joyce, R.A. \& S.D. Gillespie, 2000. Beyond Kinship: Social and Material Reproduction in House Societies. Philadelphia (PA): University of Pennsylvania Press.

Kertzer, D.I., 1988. Ritual, Politics, and Power. New Haven (CT): Yale University Press.

Kertzer, D.I., 1991. The role of ritual in state-formation, in Religious Regimes and State- Formation: Perspectives from European Ethnology, ed. E.R. Wolf. New York (NY): State University of New York Press, 85-104.

Lesure, R., 1999. On the genesis of value in early hierarchical societies, in Material Symbols: Culture and Economy in Prehistory, ed. J.E. Robb. Carbondale (IL): Southern Illinois University, 23-55.

Lévi-Strauss, C., 1982. The Way of the Masks. Seattle (WA): University of Washington Press.

Lévi-Strauss, C., 1987. Anthropology and Myth: Lectures, 1951-1982. New York (NY): Blackwell Publishers.

De Lucia, K., 2008. Looking beyond gender hierarchy: rethinking gender at Teotihuacan, Mexico, in Gender, Households, and Society: Unraveling the Threads of Past and Present, eds. E.M. Brumfiel \& C. Robin (Archeological Papers 18.) Washington (DC): American Anthropological Association, 17-36.

Manzanilla, L.R., 2002. Houses and ancestors, altars and relics: mortuary patterns at Teotihuacan, central Mexico, in The Space and Place of Death, eds. H. Silverman \& D.B. Small. (Archeological Papers 11.) Washington (DC): American Anthropological Association, 55-65.

Manzanilla, L.R., 2007. Las 'casas' nobles de los barrios de Teotihuacan: estructuras exclusionistas en un entorno corporativo. Memoria 2007 de El Colegio Nacional, Mexico, 453-70.

Manzanilla, L.R., 2009a. Corporate life in apartment and barrio compounds at Teotihuacan, central Mexico, in Domestic Life in Prehispanic Capitals: a Study of Specialization, Hierarcy, and Ethnicity, eds. L.R. Manzanilla \& C. Chapdelaine. Ann Arbor (MI): Memoirs of the Museum of Anthropology, University of Michigan, 21-42.

Manzanilla, L.R., 2009b. Introduction: Mesoamerican domestic structures, compounds, and neighborhoods, in Domestic Life in Prehispanic Capitals: a Study of Specialization, Hierarchy, and Ethnicity, eds. L.R. Manzanilla \& C. Chapdelaine. Ann Arbor (MI): Memoirs of the Museum of Anthropology, University of Michigan, 3-5.

Manzanilla, L.R., M. Millones \& M. Civera, 1999. Los entierros de Oztoyahualoc 15B: N6W3, in Prácticas funerarias en la Ciudad de los Dioses: los enterramientos humanos de la antigua Teotihuacan, eds. L.R. Manzanilla \& C. Serrano. Mexico City: Instituto de Investigaciones Antropológicas, Universidad Nacional Autónoma de México, 247-83.

McCafferty, G.G., 2007. Altar egos: domestic ritual and social identity in Postclassic Cholula, Mexico, in Commoner Ritual and Ideology in Ancient Mesoamerica, eds. N. Gonlin \& J.C. Lohse. Boulder (CO): University Press of Colorado, 213-50.

Millon, R., 1973. The Teotihuacán Map. Austin (TX): University of Texas Press.

Millon, R., 1981. Teotihuacan: city, state, and civilization, in Supplement to the Handbook of Middle American Indians, eds. V.A. Bricker \& J.A. Sabloff. Austin (TX): University of Texas Press, 195-243.

Millon, R., 1988. The last years of Teotihuacan dominance, in The Collapse of Ancient States and Civilizations, eds. N. Yoffee \& G.L. Cowgill. Tucson (AZ): University of Arizona Press, 102-64.

Milner, G.R., J.W. Wood \& J.L. Boldsen, 2000. Paleodemography, in Biological Anthropology of the Human Skeleton, eds. M.A. Katzenberg \& S.R. Saunders. New York (NY): Wiley-Liss, 467-97.

Ortner, S.B. \& H. Whitehead, 1981. Sexual Meanings, the Cultural Construction of Gender and Sexuality. Cambridge: Cambridge University Press.

Parker Pearson, M., 1982. Mortuary practices, society, and ideology: an ethnoarchaeological study, in Symbolic and Structural Archaeology, ed. I. Hodder. Cambridge: Cambridge University Press, 99-113.

Parker Pearson, M., 1999. The Archaeology of Death and Burial. College Station (TX): Texas A\&M University Press.

Pasztory, E., 1997. Teotihuacan: an Experiment in Living. Norman (OK): University of Oklahoma Press.

Rappaport, R.A., 1979. Ecology, Meaning, and Religion. Berkeley (CA): North Atlantic Books.

Rappaport, R.A., 1984. Pigs for the Ancestors. 2nd edition. New Haven (CT): Yale University Press.

Rattray, E.C., 2001. Teotihuacan: Ceramics, Chronology, and Cultural Trends. Mexico City: Instituto Nacional de Antropología e Historia.

Robertson, I.G., 2001. Mapping the Social Landscape of an Early Urban Center: Socio-spatial Variation in Teotihuacan. Unpublished PhD dissertation, School of Human Evolution and Social Change, Arizona State University.

Robin, C., 2004. Social diversity and everyday life within Classic Maya settlements, in Mesoamerican Archaeology: Theory and Practice, eds. J.A. Hendon \& R.A. Joyce. Malden (MA): Blackwell Publishing, 148-68. 
Sanders, W.T., J.R. Parsons \& R.S. Santley, 1979. The Basin of Mexico: Ecological Processes in the Evolution of a Civilization. New York (NY): Academic Press.

Saxe, A.A., 1970. Social Dimensions of Mortuary Practices. PhD Dissertation. Ann Arbor (MI): Department of Anthropology, University of Michigan.

Sempowski, M.L., 1992. Economic and social implications of variations in mortuary practices at Teotihuacan, in Art, Ideology, and the City of Teotihuacan, ed. J.C. Berlo. Washington (DC): Dumbarton Oaks, 27-58.

Sempowski, M.L., 1994. Mortuary practices at Teotihuacan, in Mortuary Practices and Skeletal Remains at Teotihuacan, eds. M.L. Sempowski \& M.W. Spence. Salt Lake City (UT): University of Utah Press, 1-314

Sempowski, M.L., 1999. The potential role of human interment in household ritual at Tetitla, in Prácticas funerarias en la Ciudad de los Dioses: los enterramientos humanos de la antigua Teotihuacan, eds. L.R. Manzanilla \& C. Serrano. Mexico City: Universidad Nacional Autónoma de México, 473-502.

Shennan, S., 1997. Quantifying Archaeology. Edinburgh: Edinburgh University Press.

Silverblatt, I., 1988. Women in states. Annual Review of Anthropology 17, 426-60.

Spence, M.W., 1974. Residential practices and the distribution of skeletal traits in Teotihuacan, Mexico. Man 9(2), 262-73.

Spence, M.W., 1987. The scale and structure of obsidian production, in Teotihuacan: nuevos datos, nuevos sintesis, nuevos problemas, eds. E.M. de Tapia \& E.C. Rattray. Mexico City: Instituto de Investigaciones Antropológicas, Universidad Autónoma de México, 430-50.

Spence, M.W., 1994. Human skeletal materials from Teotihuacan, in Mortuary Practices and Skeletal Remains at Teotihuacan, eds. M.L. Sempowski \& M.W. Spence. Salt Lake City (UT): University of Utah Press, 315-453.

Spence, M.W., 2002. Domestic ritual in Tlailotlacan, Teotihuacan, in Domestic Ritual in Ancient Mesoamerica, ed. P. Plunket. (Monograph 46.) Los Angeles (CA): Cotsen Institute of Archaeology, University of California, 53-66.

Spence, M.W. \& L. Gamboa Cabezas, 1999. Mortuary practices and social adaptation in the Tlailotlacan enclave, in Prácticas funerarias en la Ciudad de los Dioses: los enterramientos humanos de la antigua Teotihuacan, eds. L. Manzanilla \& C. Serrano. Mexico City: Instituto de Investigaciones Antropológicas, Universidad Nacional Autónoma de México, 173-201.

Spence, M.W., C.D. White, E.C. Rattray \& F.J. Longstaffe, 2005. Past lives in different places: the origins and relationships of Teotihuacan's foreign residents, in Settlement, Subsistence, and Social Complexity: Essays Honoring the Legacy of Jeffrey R. Parsons, ed. R.E. Blanton. Los Angeles (CA): Cotsen Institute of Archaeology, University of California, 155-97.

Stark, B.L., 2008. Archaeology and ethnicity in Postclassic Mesoamerica, in Ethnic Identity in Nahua Mesoamerica: the View from Archaeology, Art History, Ethnohistory, and Contemporary Ethnography, eds. F.F. Berdan, J.K.
Chance, A.R. Sandstrom, B.L. Stark, J. Taggart \& E. Umberger. Salt Lake City (UT): The University of Utah Press, 38-63.

Stockett, M.K., 2005. On the importance of difference: reenvisioning sex and gender in ancient Mesoamerica. World Archaeology 37, 566-78.

Storey, R., 1992. Life and Death in the Ancient city of Teotihuacan: a Modern Paleodemographic Synthesis. Tuscaloosa (AL): University of Alabama Press.

Storey, R., 1994. Addendum: burial descriptions from the apartment compound Tlajinga 33, in Mortuary Practices and Skeletal Remains at Teotihuacan, eds. M.L. Sempowski \& M.W. Spence. Salt Lake City (UT): University of Utah Press, 429-46.

Storey, R. \& R.J. Widmer, 1989. Household and community structure of a Teotihuacan apartment compound S3W1:33 of the Tlajinga Barrio, in Households and Communities, eds. S. MacEachern, D.J.W. Archer \& R.D. Garvin. Calgary (AB): Archaeological Association of the University of Calgary, 407-15.

Strathern, M., 1988. The Gender of the Gift: Problems with Women and Problems with Society in Melanesia. Berkeley (CA): University of California Press.

Sugiyama, S., 2005. Human Sacrifice, Militarism, and Rulership: Materialization of State Ideology at the Feathered Serpent Pyramid, Teotihuacan. Cambridge: Cambridge University Press.

Sullivan, K.S., 2006. Specialized production of San Martin Orange Ware at Teotihuacan, Mexico. Latin American Antiquity 17, 23-53.

Uruñuela, G. \& P. Plunket, 2002. Lineages and ancestors: the Formative mortuary assemblages of Tetimpa, Puebla, in Domestic Ritual in Ancient Mesoamerica, ed. P. Plunket. Los Angeles (CA): Cotsen Intitute of Archaeology, 20-30.

Uruñuela, G. \& P. Plunket, 2007. Tradition and transformation: village ritual at Tetimpa as a template for early Teotihuacan, in Commoner Ritual and Ideology in Ancient Mesoamerica, eds. N. Gonlin \& J.C. Lohse. Boulder (CO): University Press of Colorado, 33-54.

Watanabe, J.M., 1992. Maya Saints and Souls in a Changing World. Austin (TX): University of Texas Press.

White, C.D., R. Storey, F.J. Longstaffe \& M.W. Spence, 2004. Immigration, assimilation, and status in the ancient city of Teotihuacan: stable isotopic evidence from Tlajinga 33. Latin American Antiquity 15, 176-98.

Yaeger, J., 2000. The social construction of communities in the Classic Maya countryside, in The Archaeology of Communities: a New World Perspective, eds. M.A. Canuto \& J. Yaeger. London: Routledge, 123-42.

\section{Author biography}

Sarah C. Clayton is an Assistant Professor in the Department of Anthropology at the University of Wisconsin-Madison. Clayton's research focuses on mortuary ritual and social identity among rural and urban sectors of ancient Teotihuacan and on intraregional socio-political and economic organization in the greater Classic period Basin of Mexico. 


\section{CAMBRIDGE}

\section{JOURNALS}

\section{Archaeological Dialogues}

\section{Editors}

Ton Derks, VU University Amsterdam, The Netherlands

Michael Dietler, University of Chicago, USA

Fokke Gerritsen, Netherlands Institute in Turkey, Istanbul, Turkey

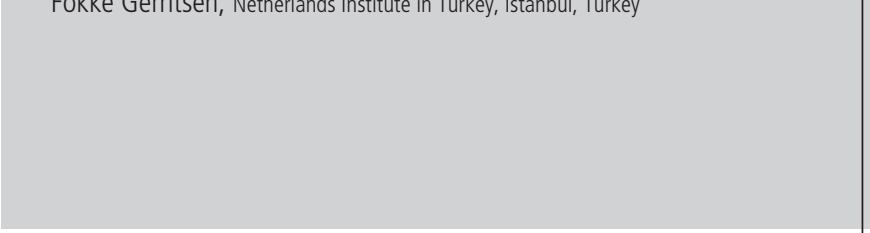

Archaeology is undergoing rapid changes in terms of its conceptual framework and its place in contemporary society. In this challenging intellectual climate,

Archaeological Dialogues has become one of the leading journals for debating innovative issues in archaeology. Rooted in European archaeology, it now serves the international academic community for discussing the theories and practices of archaeology today. True to its name, debate takes a central place in Archaeological Dialogues.

\section{Price information}

is available at: http://journals.cambridge.org/ard

\section{Free email alerts}

Keep up-to-date with new material - sign up at http://journals.cambridge.org/alerts

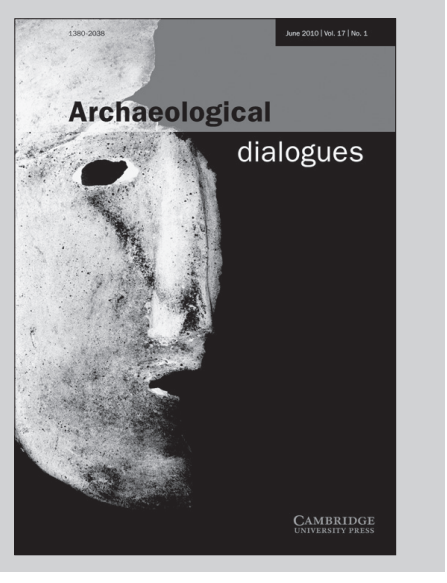

Archaeological Dialogues is available online at: http://journals.cambridge.org/ard

To subscribe contact Customer Services

in Cambridge:

Phone +44 (0)1223 326070

$\mathrm{Fax}+44(0) 1223325150$

Email journals@cambridge.org

\section{in New York:}

Phone +1 (845) 3537500

Fax +1 (845) 3534141

Email

subscriptions_newyork@cambridge.org

For free online content visit: http://journals.cambridge.org/ard 